\title{
Marsupials as introduced species: Long- term anthropogenic expansion of the marsupial frontier and its implications for zoogeographic interpretation
}

\section{Thomas E. Heinsohn}

Invasive Animals Co-operative Research Centre and Institute for Applied Ecology, University of Canberra, Australia; Visiting Fellow, Archaeology and Natural History, Research School of Pacific and Asian Studies, Australian National University, Australia

Thomas.Heinsohn@canberra.edu.au

\section{Introduction: Those 'dull and inferior ... Marsupials'}

Traditionally, Southern mammals such as the marsupials and monotremes of Australasia have been viewed as further down the evolutionary tree and thus inferior to the placental mammals of Afro-Eurasia and the Americas. This Eurocentrism or Northern-Hemisphere-centrism is typified in the writings of turn-of-the-century British naturalist McCabe (1910), who wrote a paper entitled 'Australia - A Museum of Living Antiquities' in which he characterised the continent as a last bastion for inferior species:

'...circumstances point to an invasion of Australia by the land-bridge from Asia ... Under the stress of the new carnivores of the northern world the dull inferior Monotremes and Marsupials escaped over the land-bridge to the southern continent.' (McCabe 1910:44)

Renowned late $19^{\text {th }}$ century German naturalist Haeckel (1893) took Eurocentrism a step further by suggesting that the minute one crosses the Wallace Line, which marks the boundary between the Oriental faunal region of Eurasia and the Australasian (or Australian) faunal region, one is, in effect, stepping back in time to a world of primitive species:

'Crossing the narrow but deep Lombok Strait [Wallace's Line] we go with a single step from the Present Era to the Mesozoicum.' (Haeckel 1893:5) 
We now know that there was never a Cenozoic land bridge between the Eurasian continent and Australia, and that marsupials and monotremes reached Australasia via southern Gondwanan connections, but the McCabian and Haeckelian-type views of general Northern evolutionary ascendancy and biological chauvinism lingered on well into the second half of the $20^{\text {th }}$ century (as discussed in Calaby 1984 and Heinsohn 2006a). We now also appreciate that the Australasian marsupial fauna contains a full spectrum of forms adapted to various niches, some of which proved to be quite vulnerable to foreign invasive species such as dingos, foxes, cats, rabbits and humans, and some of which proved to be quite resilient and potentially invasive themselves - for example, Australia's recent challenges in managing the ecological impacts of over-abundant eastern grey kangaroo Macropus giganteus populations in periurban parks and reserves. Indeed, kangaroos Macropus spp. along with many other marsupials have proved highly adapted to the Australian environment, with macropodids discovered to have one of the most energy-efficient modes of locomotion known for a terrestrial mammal (Dawson 1995; Flannery 1997; Tyndale-Biscoe 2005; Van Dyck and Strahan 2008). Similarly, another marsupial, the common brushtail possum Trichosurus vulpecula, is renowned for its ability to adapt to both the urban and agricultural environment and actively invades or reinvades these newly created highly anthropogenic landscapes and niches. Ironically, among the vulnerable Australasian native mammals that are now either extinct or threatened are suites of native placental murid rats derived from waif-dispersing Asian ancestors, and this parallels the status of many recently extinct or threatened marsupial species with Gondwanan origins (Flannery et al. 1990; Van Dyck and Strahan 2008). Thus in the biogeography of continents and islands, it is probably evolution in isolation more than phylogenetic history that determines the vulnerability of a species. In modern Australasia with its extensive human impacts, there are both 'losers' and 'winners' among the extant marsupials, just as there are 'losers' and 'winners' among the native placental murid rats (Flannery et al. 1990; Low 2002; Van Dyck and Strahan 2008).

As an inverse test of their adaptability, this paper aims to review the success of Australasian (Australidelphian) marsupials as introduced species on foreign landmasses. This is assessed through literature review combined with some of the author's own fieldwork data on anthropogenic biological invasions by translocated marsupials in the Indo-Australian Archipelago. A significant epistemological problem encountered in such a study is that while marsupial introductions in regional archipelagos during recent historic times for the most part appear to have been historically recorded, those that occurred in the prehistoric past were not. Thus prehistoric marsupial translocations have had to be reconstructed from a combination of palaeontological and archaeological data, combined with other lines of evidence such as molecular systematics and broader ethnozoological and biogeographic contextual analysis. Such an analysis enables the uncovering of prehistorically introduced 'camouflaged exotics' (Heinsohn 1997a) or 'cryptogenic' (Carlton 1996) populations of introduced marsupials on islands, which might otherwise go unnoticed by superficially appearing to be natural. This is referred to as uncovering the 'crypto-anthropogenic factor' of hidden long-term human influences on zoogeography (Heinsohn 1997a, 1998a, 2003, 2006a). 
Some of the lines of evidence considered for distinguishing translocated from naturally occurring island vertebrate populations, but here applied to marsupials, are listed below (from Heinsohn 2006a):

1. Patchy, improbable or strangely disjunct distributions;

2. Limited distributions on a landmass, where a species appears to have only arrived comparatively recently and the biological invasion is still in progress;

3. Occurrences on islands that follow a commensal or semi-commensal pattern where species are only found in and around human settlements or other disturbed and highly anthropogenic habitats;

4. Molecular systematics evidence, such as genetic similarity over wide inter-island distributions, that may indicate recent introduction;

5. Sudden appearances of species in archaeological sequences;

6. A lack of fossil or subfossil material in palaeontological or archaeological sequences that may indicate recent introduction;

7. Ethnozoological evidence of long associations between humans and certain wild species that are known to be carried around in watercraft as pets, or for food, utilitarian, trade or ceremonial purposes;

8. Island assemblages of vertebrates that favour human-associated species over natural dispersal ability;

9. Directly documented accounts of species introduction, such as written historical records or oral historical records of translocation and/or subsequent biological invasions by a successfully introduced species;

10. Analogy from biogeographic patterns created by historically documented biological invasions by introduced species; and

11. Big-picture analysis of the global distribution of invasive species and their current invasion frontier, with back-tracing of their probable historic/prehistoric anthropogenic invasion pathway from an original natural source area, so as to distinguish their 'natural' versus introduced/anthropogenic distributions.

In light of the potential ambiguity of single strands of evidence, it is often a combination of some of these indicators that tips the scales of probability in favour of considering translocation by human agency.

Given the problem of camouflaged exotics or cryptogenic populations of marsupials in the Indo-Australian Archipelago, a phenomenon which for the most part has been recognised only recently in relation to marsupials (as reviewed by Heinsohn 2006a), a further aim of this paper is to assess the degree to which the classic zoogeographers and later observers were aware of the aforementioned crypto-anthropogenic factor in marsupial zoogeography. Did varying degrees of naivety or awareness influence their respective interpretations of island marsupial faunas and the placement of various zoogeographic lines (Figure 1)? Thus this interdisciplinary review combines biogeographic analysis with a history of zoogeographic ideas. In particular, this article is juxtaposed with an earlier paper by Gilmore (1977), 'The success of marsupials as introduced species', to show how much our collective knowledge of marsupial biogeography has progressed in the past few decades. 


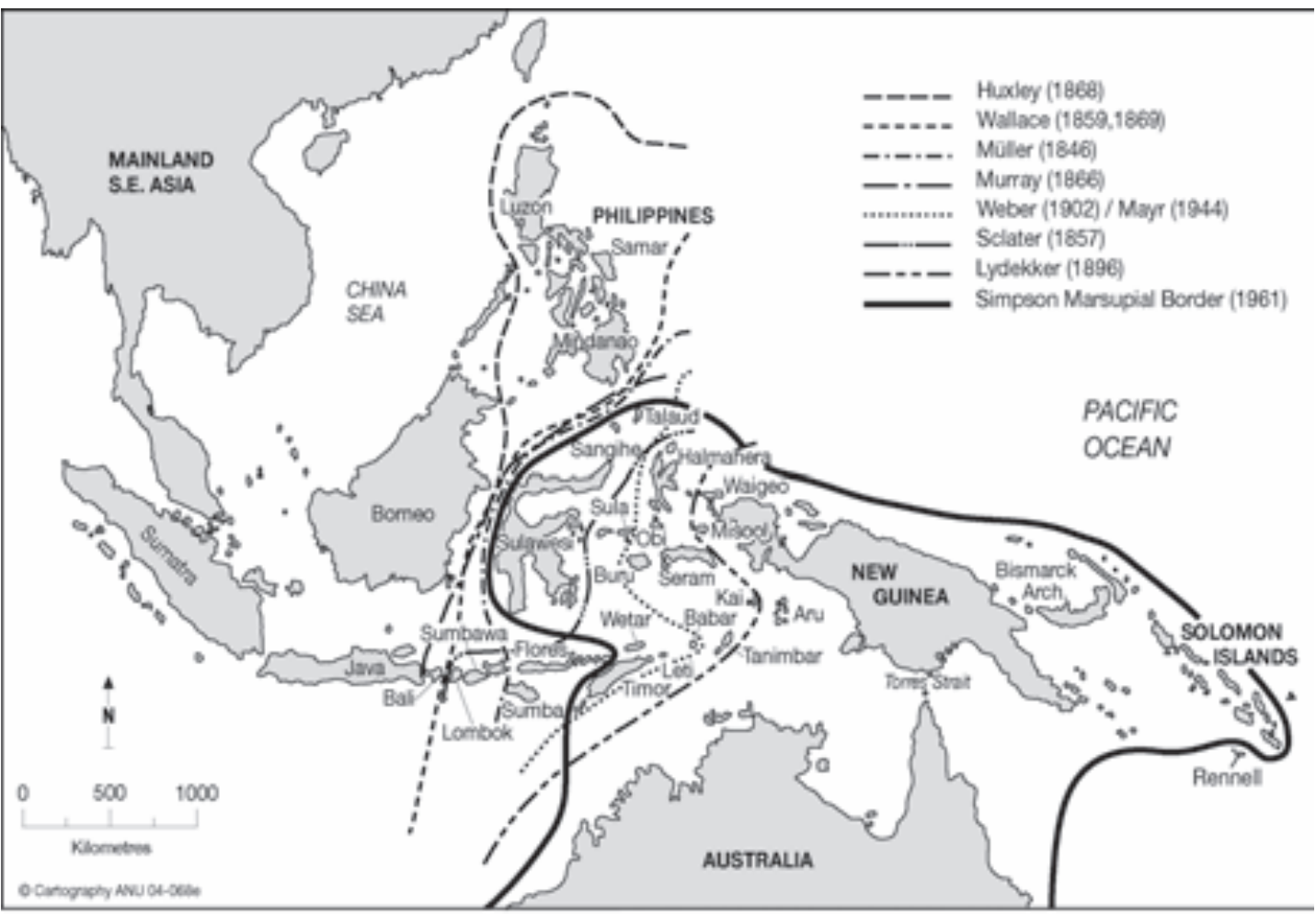

Figure 1. Some traditional zoogeographic boundary lines in the Indo-Australian Archipelago most of which attempt to define the demarcation between Asian and Australian faunas. Simpson's Marsupial Line (1961) is marked in bold. Simpson naively treats this boundary as the natural distributional limit of marsupials in the tropics (after Heinsohn 2006a)

\section{Study area: The realm of the Australidelphian (Australasian) marsupial}

The study area includes all of the regions of the world in which Australidelphian (Australasian) marsupials occur as natural or introduced species (not to be confused with the Ameridelphian marsupials of the Americas). For Australidelphian marsupials this includes: (1) Australia and its continental shelf islands such as Tasmania, which together have approximately 158 marsupial species; (2) New Guinea and its fringing Papuan subregion continental shelf islands, which have about 80 species; (3) the oceanic Wallacean islands of Eastern Indonesia, comprising the Lesser Sundas, Sulawesi subregion and the Moluccas, which collectively have about 12 species (seven of which are Wallacean endemics); (4) the oceanic northern Melanesian islands (the Bismarck Archipelago and Solomon Islands) of Near Oceania, which have about seven species (many, or possibly all, of which may be introduced); (5) New Zealand and its satellite islands in southern Remote Oceania, which have six recently introduced species; (6) the Hawaiian Islands in northern Remote Oceania, which have one recently introduced species on Oahu Island; and (7) the British Isles in the European Palaearctic region, which has a single recently introduced species (Tomich 1986; Whitten et al. 1987; Corbet and Hill 1992; Flannery 1994; Flannery 1995a, b; Monk et al. 1997; Heinsohn 2001a, 2002a, b, c, 2003, 2004a, b, 2005a, b, c, 2006a; Ziegler 2002; Long 2003; Helgen and Flannery 2004; King 2005; Nowak 2005; Heinsohn and Hope 2006; Harris and Yalden 2008; Van Dyck and Strahan 2008).

A particular focus of this study, however, is the tropical Australasian portion of the IndoAustralian Archipelago that stretches to the east of the Oriental Region. The term 'IndoAustralian Archipelago' can be confusing in that it is generally used as a synonym for 'Malay Archipelago' (islands stretching from the Malay Peninsula to New Guinea), but some authors use it in a broader sense to also include Australia and the islands of Near Oceania (etymology reviewed in Heinsohn 2006a). Some significant recognised boundaries include the Wallace/ Huxley Line, which marks the eastern edge of the Sundaic continental shelf and the eastern 
limit of complex continental Oriental Region faunas (Figure 2). This is paralleled further east by Lydekker's Line, which marks the western edge of the Meganesian continental shelf and the western limit of complex continental Meganesian (also called 'Greater Australian', 'Sahul' or 'Australo-Papuan') faunas. Between the continental Sundaic region and continental Meganesia lie the oceanic Wallacean islands with depauperate and unbalanced oceanic faunas that exhibit limited Oriental influences from the west and limited Meganesian (AustraloPapuan) influences from the east. To the east of Meganesia lie the oceanic northern Melanesian islands (the Bismarck Archipelago and Solomon Islands) of Near Oceania, which also have depauperate and unbalanced oceanic faunas that exhibit salient New Guinean influences on their biotas (Heinsohn 2006a; Heinsohn and Hope 2006; Morwood and Van Oosterzee 2007). For a delineation of specific tropical Australasian zoogeographic subregions to the immediate east of the Wallace Line, see Figure 3.

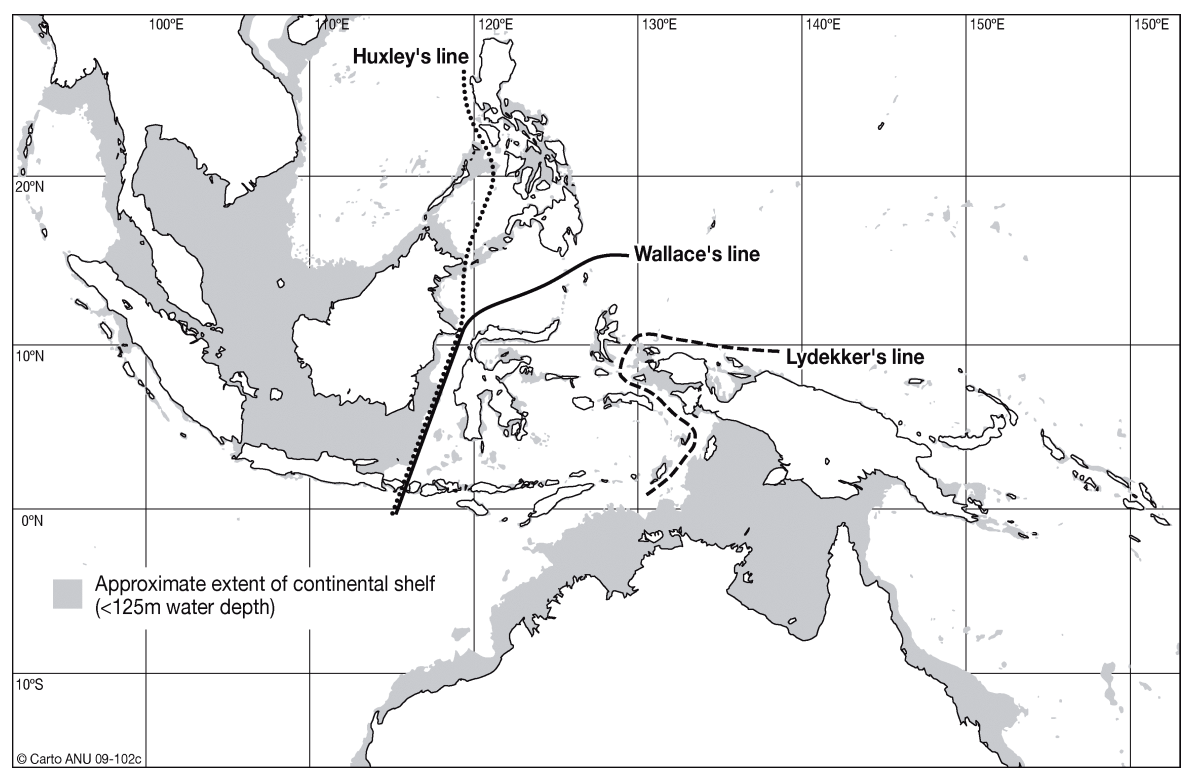

Figure 2. Indo-Australian Archipelago showing land and sea during the Last Glacial Maximum at c. 19,000 BP when sea levels may have fallen by $120 \mathrm{~m}$ to $130 \mathrm{~m}$. The Wallace/Huxley Line essentially marks the eastern edge of the Sunda continental shelf and eastern limit of complex Oriental continental faunas; while Lydekker's Line essentially marks the western edge of the Sahul/ Greater Australian continental shelf and the western limit of complex Australo-Papuan continental faunas. Between these two lines lie the oceanic Wallacean Islands (after Heinsohn 2006a)

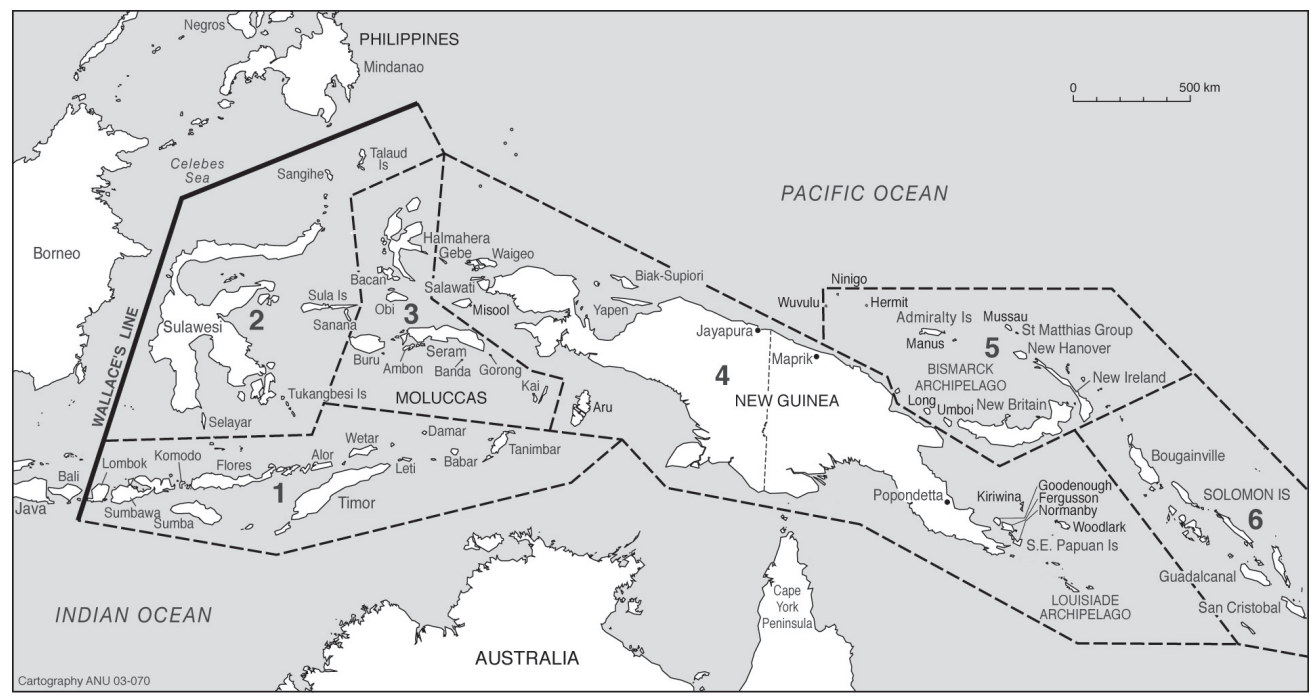

Figure 3. Map of the zoogeographic subregions to the immediate east of the Wallace Line. (1) Lesser Sundas; (2) Sulawesi Subregion; (3) Moluccas; (4) Papuan Subregion; (5) Bismarck Archipelago; and (6) Solomon Islands. Wallacea is comprised of subregions 1, 2 and 3; while Near Oceania is comprised of subregions 5 and 6 (after Heinsohn 2003) 
During times of significantly lowered sea levels, such as the Last Glacial Maximum (LGM) at about 19,000 BP, when sea levels fell by $120 \mathrm{~m}$ to $130 \mathrm{~m}$, large areas of both the Asian Sunda shelf and the Greater Australian Sahul shelf became exposed (Figure 2). In the west, this caused the Greater Sunda islands of Sumatra, Java, Bali and Borneo to coalesce with each other and the Asian mainland to form a continuous land bridge stretching from the Malay Peninsula to Bali and Borneo-Palawan. In the east, this caused New Guinea and its continental satellites such as Aru to coalesce with Australia and Tasmania to form a single Meganesian or Greater Australian continental landmass. Despite some limited internal coalescences, however, the intervening Wallacean islands (Lesser Sundas, Sulawesi subregion and Moluccas), separated by deep channels and seas, remained insular and this prevented the formation of a land bridge from Asia to Australia (Figure 2). Similarly, due to a series of deep intervening channels and seas, the northern Melanesian islands (the Bismarck Archipelago and Solomon Islands) of Near Oceania, despite internal coalescence within some island groups, also remained insular and oceanic and never formed land bridges with New Guinea or between principal island subregions. Furthermore, the Philippines (other than Palawan with its Bornean connections), despite some internal coalescences, also remained significantly insular and oceanic and thus could almost be viewed as a northern extension of oceanic Wallacea (Chappell and Shackleton 1986; Chappell 1987; Haq et al. 1987; Fairbanks 1989; Hope 1996; Hall 2001; Inger and Voris 2001; Heinsohn 2006a; Morwood and Van Oosterzee 2007).

The dominant natural vegetation of the tropical Indo-Australian Archipelago (excluding Australia) is Malesian and Papuasian rainforest and monsoon forest, but with sizeable areas of either natural or anthropogenic savannah and savannah woodland, particularly in drier parts of the archipelago such as across much of the Lesser Sundas and southern New Guinea. The highest mountains in the region occur in the central cordillera of New Guinea, which has peaks approaching $5000 \mathrm{~m}$ in altitude, with the island supporting a spectrum of lowland to montane, subalpine and alpine habitats, including sizeable areas of montane anthropogenic grasslands. In other stretches of the archipelago, such as in parts of Wallacea and the northern Melanesian islands, there are island mountain ranges that reach between $2000 \mathrm{~m}$ and $3000 \mathrm{~m}$ in altitude, many of which support significant areas of montane forest, and upland anthropogenic grasslands (Whitten et al. 1987; Hope 1996; Monk et al. 1997; Heinsohn and Hope 2006).

The earliest recorded human occupation in the Indo-Australian Archipelago is that of Homo erectus in Java to the west of the Wallace Line at about 1.2 million years ago, where both fossil remains and stone tools have been found (Bellwood 1997). However, recent discoveries of ancient stone tools, possible early anthropogenic faunal extinction (turnover) horizons, and the fossil remains of Homo floresiensis on the Lesser Sunda island of Flores, variously dating between 880,000 and 18,000 years ago, have indicated the presence of pre-modern hominids to the east of the Wallace Line in Wallacea (Morwood and van Oosterzee 2007). Indeed, the $H$. floresiensis remains recently have been interpreted as possibly belonging to a relictual preHomo erectus hominid population that was probably once widespread in Asia and was able to hang on in Flores until about 18,000 BP. Indeed, suspected possible Middle Pleistocene stone-tool assemblages and/or possible Middle Pleistocene anthropogenic faunal extinction (turnover) horizons from places such as Timor, Sulawesi and the Philippines may be indicative that early pre- $H$. erectus hominids akin to $H$. floresiensis reached other parts of Wallacea and more northerly oceanic areas such as the Philippines (Morwood and Van Oosterzee 2007; Morwood pers comm. 2009, Mulvaney Lecture, Australian National University, 13 May 2009). If this is the case, then Sulawesi, with its ancient endemic marsupials, may be the first place where hominids and marsupials came into contact.

In contrast to the above early hominid record, the initial invasion of Wallacea and Meganesia (Greater Australia or Sahul) by modern Homo sapiens is generally thought to have occurred between 40,000 and 55,000 years ago in the late Pleistocene, with the islands of the Bismarck Archipelago in Near Oceania also being colonised within a broadly similar timeframe 
(c. 40,000 BP), but slightly later for the Solomon Islands at about 32,000 BP (Bellwood 1997; Thorne et al. 1999; Wickler 2001; Leavesley and Chappell 2004; Morwood and van Oosterzee 2007; Summerhayes 2007). Following the relative stabilisation of sea levels in the lower Holocene, a further major phase of human colonisation was Austronesian-speaking agricultural and maritime peoples' expansion into Wallacea, around coastal New Guinea, into Near Oceania and the more distant Pacific islands of Remote Oceania in the past 4000 years, probably reaching New Zealand in the last millennium (Bellwood 1997; Kirch 1997; Spriggs 1997; Summerhayes 2007). This was a period that saw the rapid spread of various plant

cultivars and the domesticated triumvirate of dogs, pigs and chickens into Oceania, along with anthropogenic spread of commensal murids such as the Pacific rat Rattus exulans (Kirch 1997; Spriggs 1997; Summerhayes 2007).

In the Indo-Australian Archipelago as far as western New Guinea, the aforementioned expansion was followed by ongoing economic and cultural influences from South and Southeast Asia, including the early spice and produce trade, and finally by the impact of the 'modern' spice trade in the past millennium, which involved the mercantile empires of the Chinese, Arabs, Portuguese, Spanish, Dutch and British (Swadling 1996; Black 1999). In Australasia, Australia and New Zealand were progressively colonised by British settlers from the late $18^{\text {th }}$ and early $19^{\text {th }}$ centuries respectively (Derbyshire 1993; Nile and Clerk 1996). Most of New Guinea and northern Melanesia remained as scattered indigenous realms until the $19^{\text {th }}$ century when colonial rivalries and the lure of copra and gold led the Dutch, Germans and British to establish territories and colonial outposts (Souter 1963; Derbyshire 1993; Black 1999). The activities of the colonial acclimatisation societies in the $19^{\text {th }}$ and early $20^{\text {th }}$ centuries led to the deliberate introduction of a whole range of Eurasian, American and Australian vertebrate species to New Zealand, and a range of mostly Eurasian vertebrates to Australia, with significant impacts on both landmasses (Lever 1992; McDowall 1994; Young 2004; Heinsohn 2006a). In the tropical Indo-Australian Archipelago and Oceania, Dutch, German, British, Australian and French colonists contributed to the further spread of Oriental vertebrates such as the Javan rusa deer Cervus timorensis, adding to a traditional longterm process of translocation of multiple Oriental vertebrate species eastwards into Wallacea and Oceania by the native population, which had also carried some New Guinean/AustraloPapuan vertebrate species, including some marsupials, westwards into Wallacea (Glover 1971, 1986; Groves 1984; Heinsohn 1997a, 1998a, b, 2001a, 2002a, 2003, 2004a, 2005a, b, 2006a; Heinsohn and Hope 2006). This is the deeper historical and cultural backdrop to the anthropogenic translocation of Australasia's Australidelphian marsupials.

\section{Results and discussion: A survey of records and postulations of long-term Australidelphian marsupial translocation}

Based on literature review and some of the author's own field observations, Table 1 summarises records and postulations of historic and prehistoric Australidelphian marsupial translocations, while Table 2 summarises the postulated impact of translocation on the composition and status of island marsupial faunas. Analysis reveals that there are three principal putative source areas for translocated Australidelphian marsupials: (1) continental Australia (including continental shelf islands such as Tasmania and the Bass Strait islands); (2) continental New Guinea and the broader Papuan subregion (including continental shelf satellites such as Aru, Misool, Salawati and the southeast Papuan islands); and (3) oceanic Wallacea (specifically Sulawesi). These are discussed separately below. 


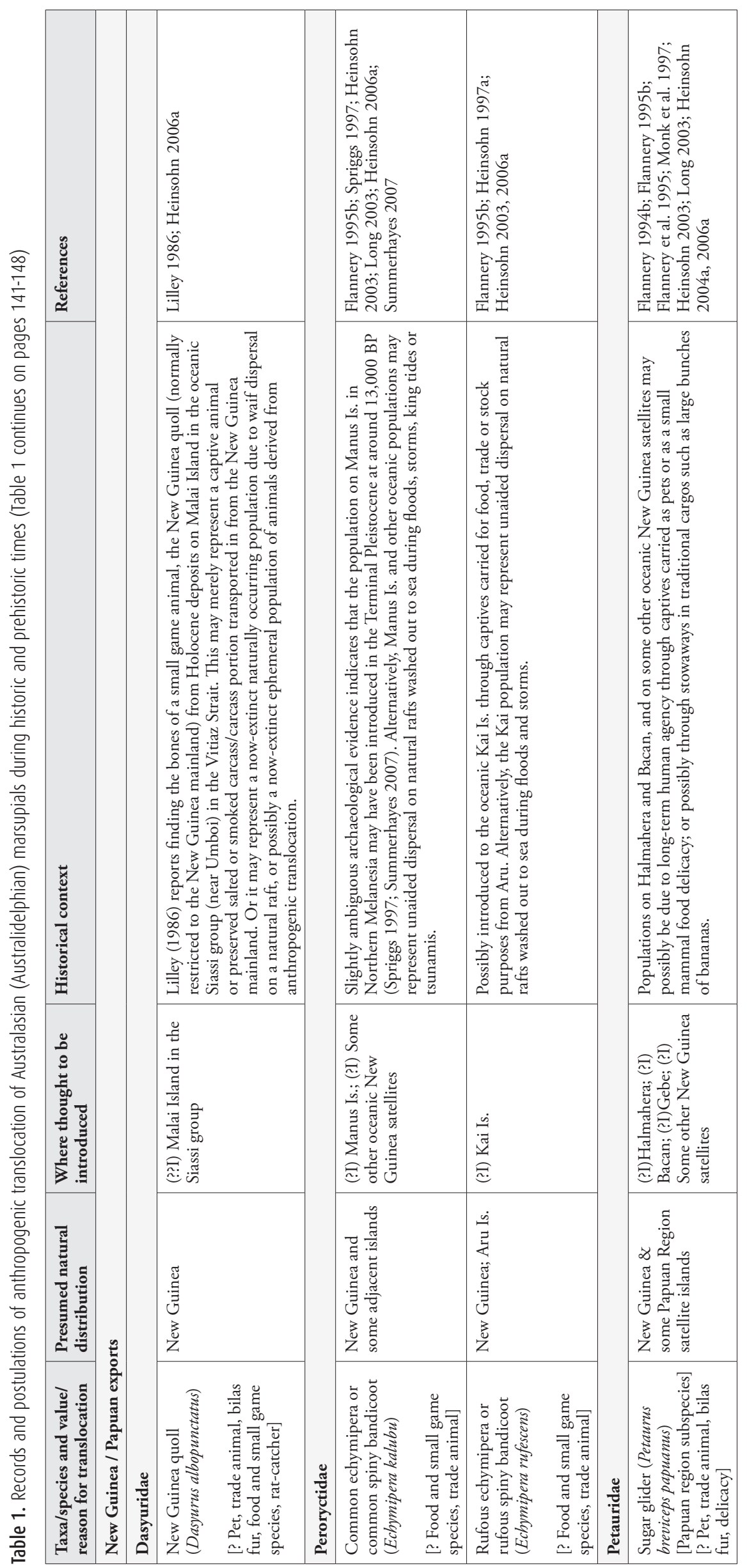




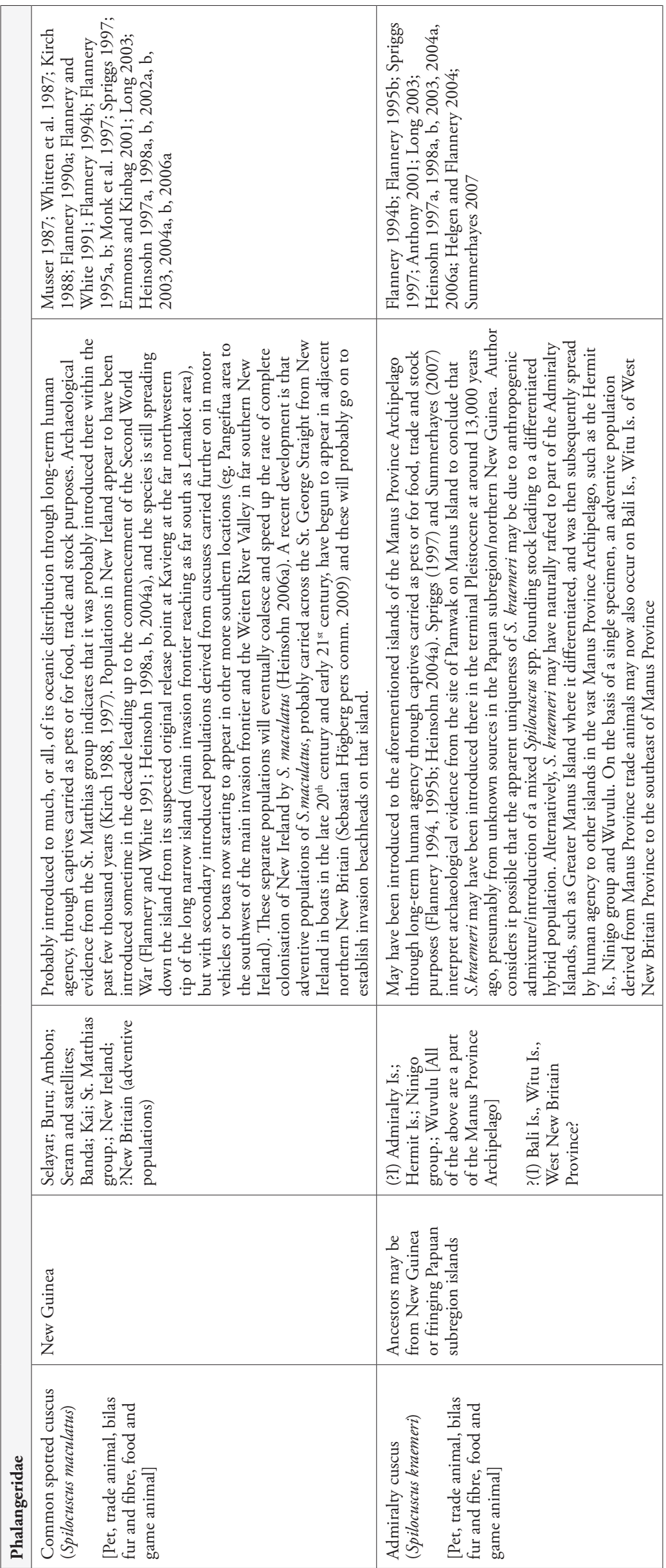




\begin{tabular}{|c|c|c|c|c|c|c|}
\hline 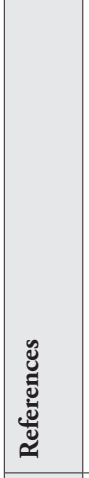 & 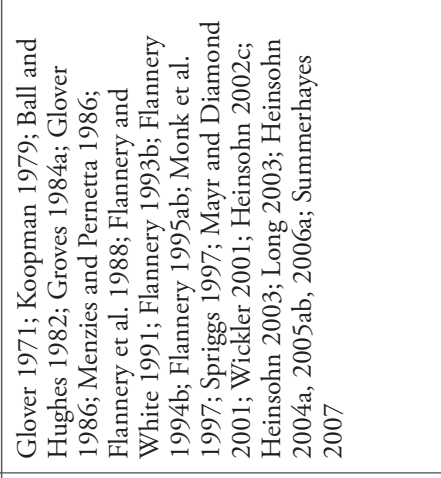 & 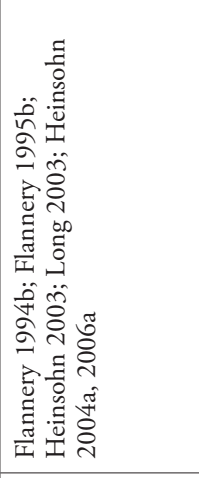 & & 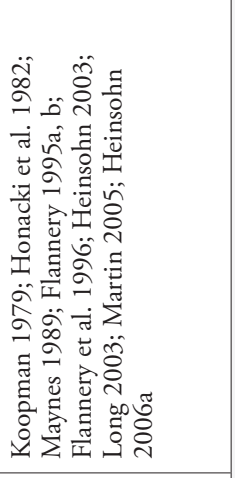 & & 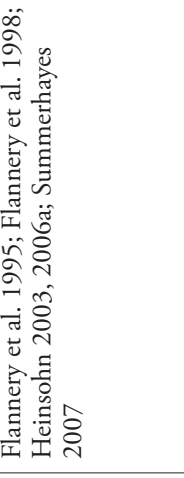 \\
\hline 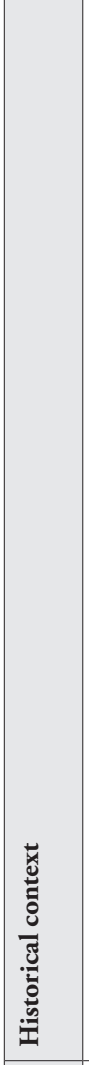 & 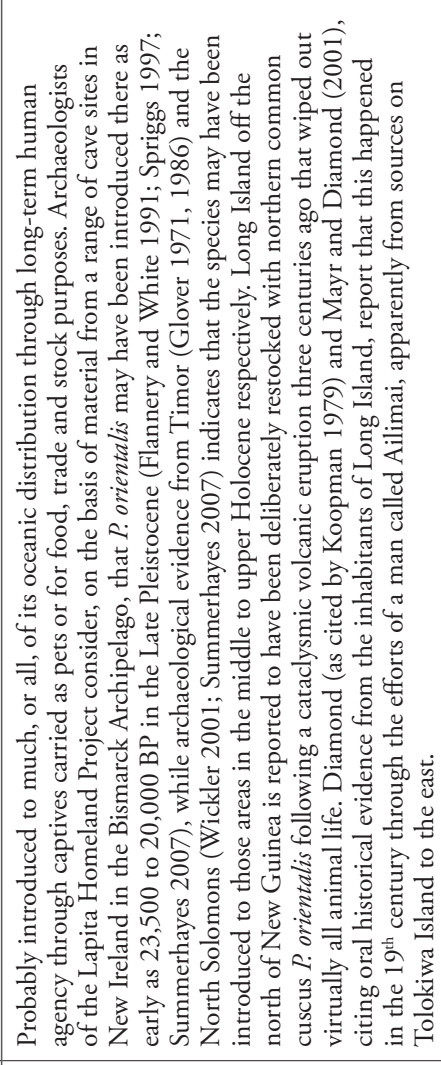 & 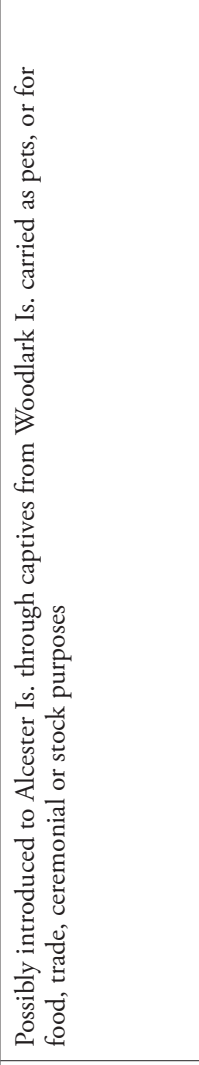 & & 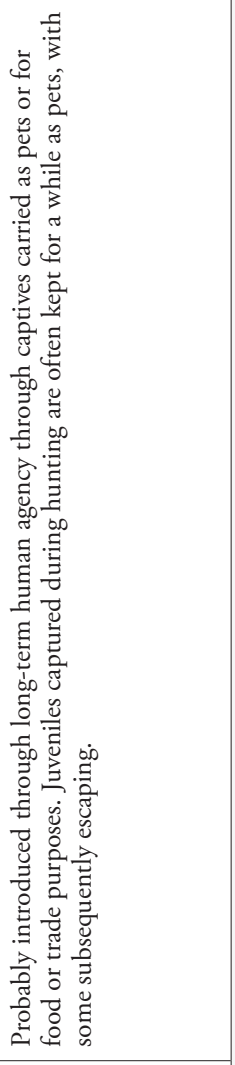 & & 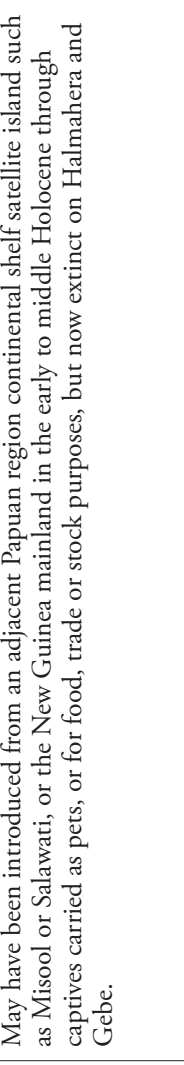 \\
\hline 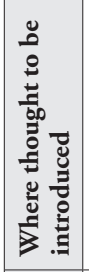 & 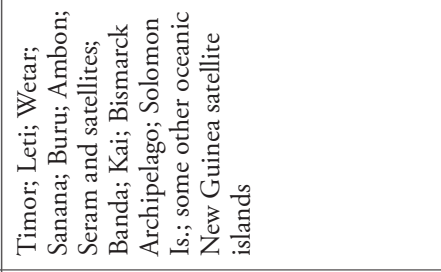 & 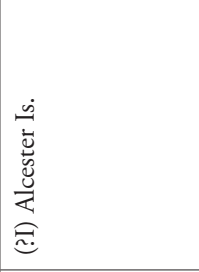 & & 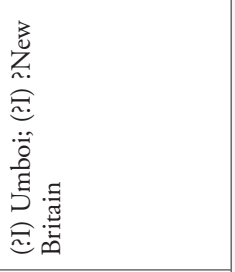 & & 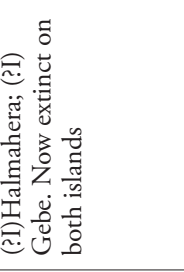 \\
\hline 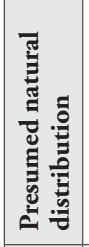 & 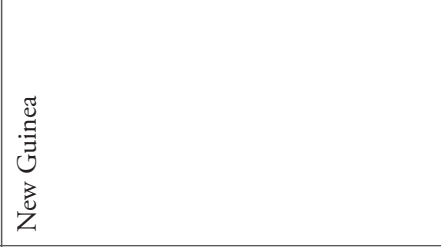 & 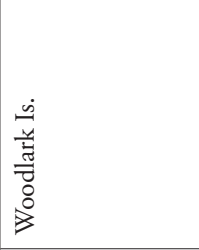 & & & & \\
\hline 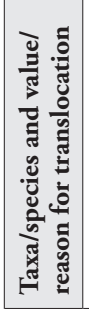 & 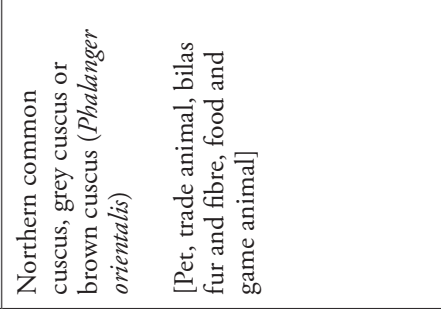 & 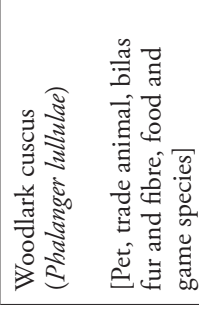 & |ֶّ & 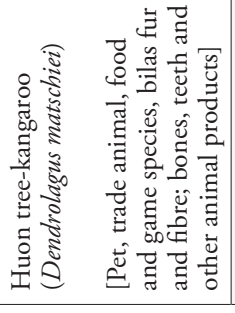 & $=$ & 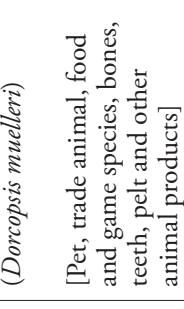 \\
\hline
\end{tabular}




\begin{tabular}{|c|c|c|c|c|}
\hline 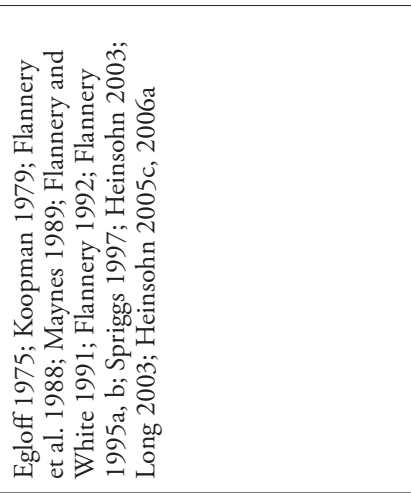 & 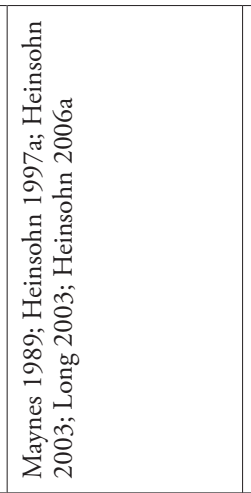 & 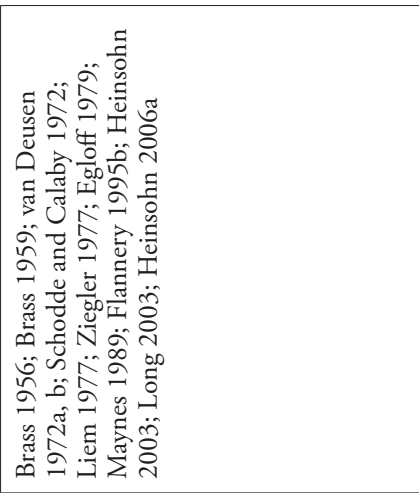 & & 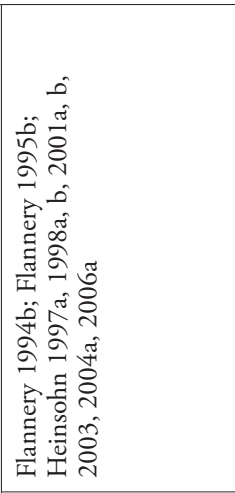 \\
\hline 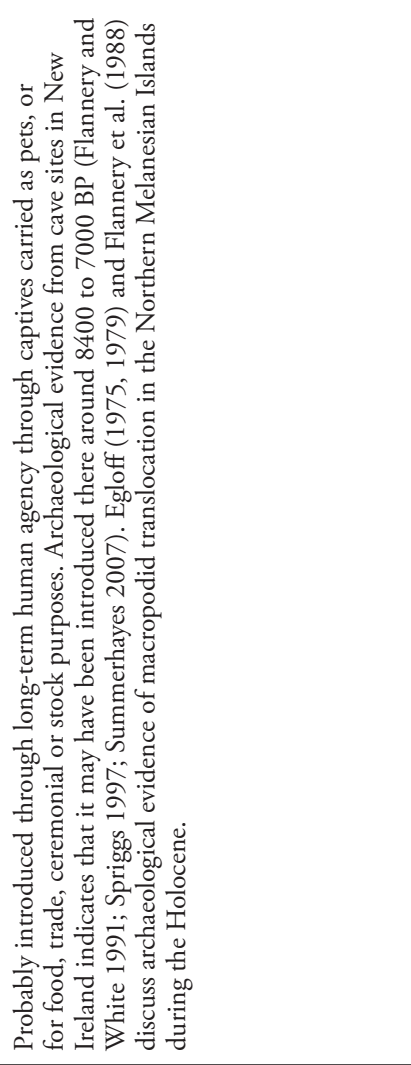 & 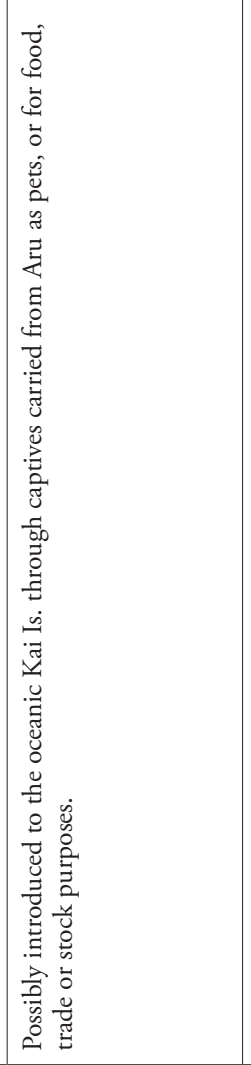 & 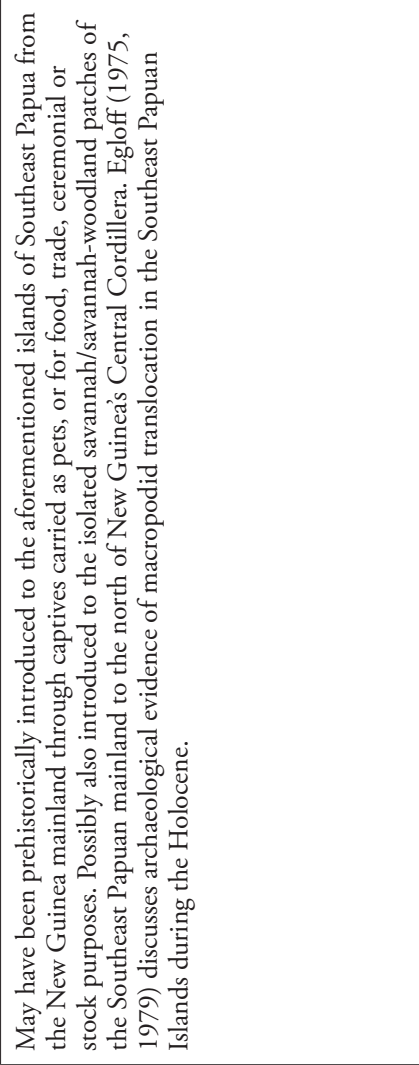 & & 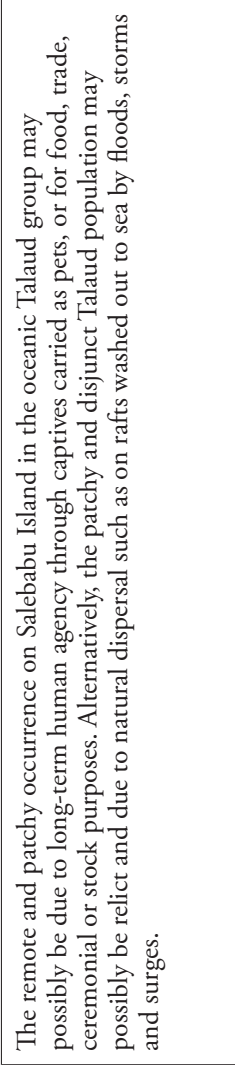 \\
\hline 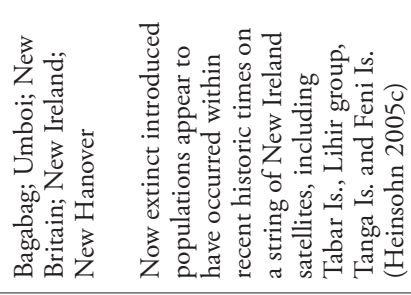 & 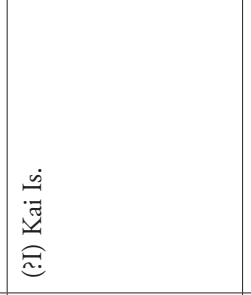 & 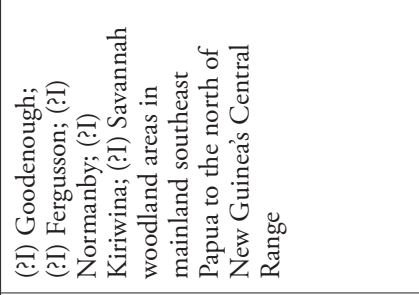 & & 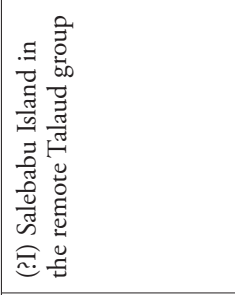 \\
\hline 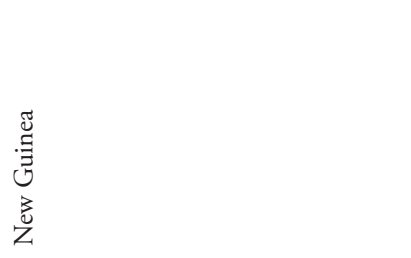 & 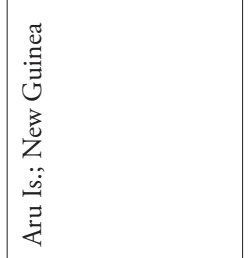 & 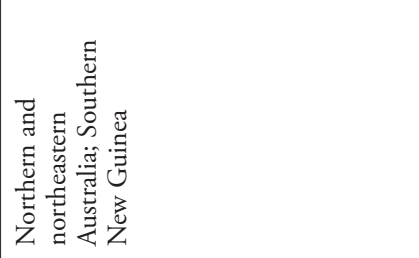 & & 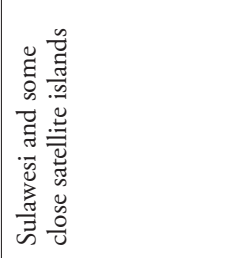 \\
\hline 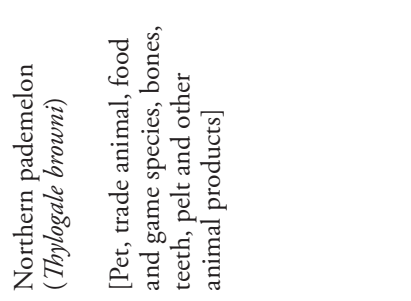 & 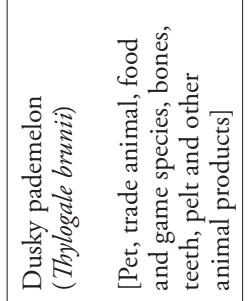 & 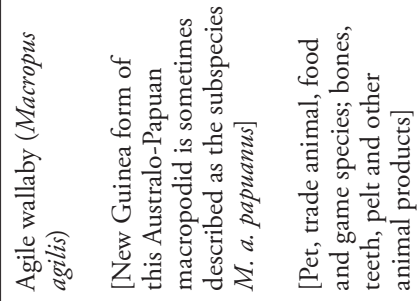 & 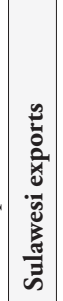 & 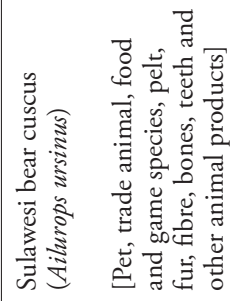 \\
\hline
\end{tabular}




\begin{tabular}{|c|c|c|c|c|c|}
\hline & & 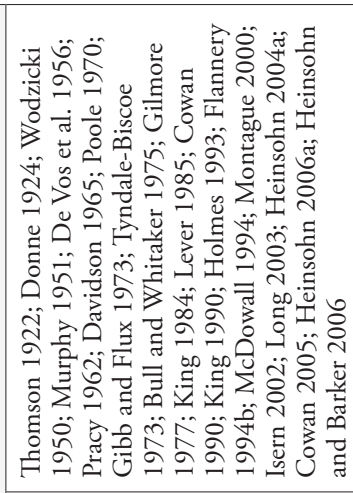 & 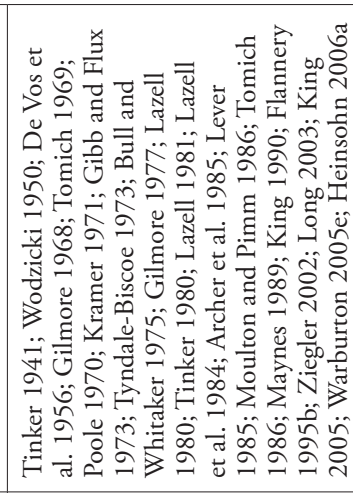 & 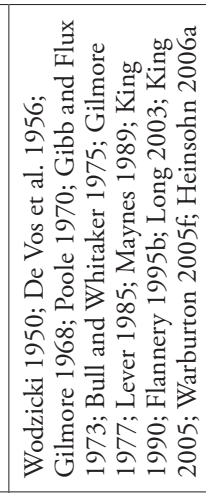 & 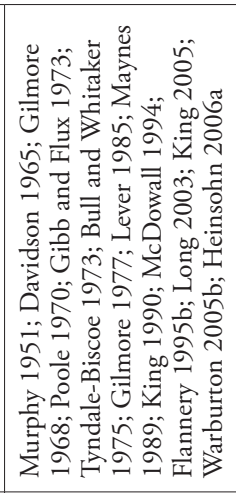 \\
\hline$\frac{0}{0}$ & & 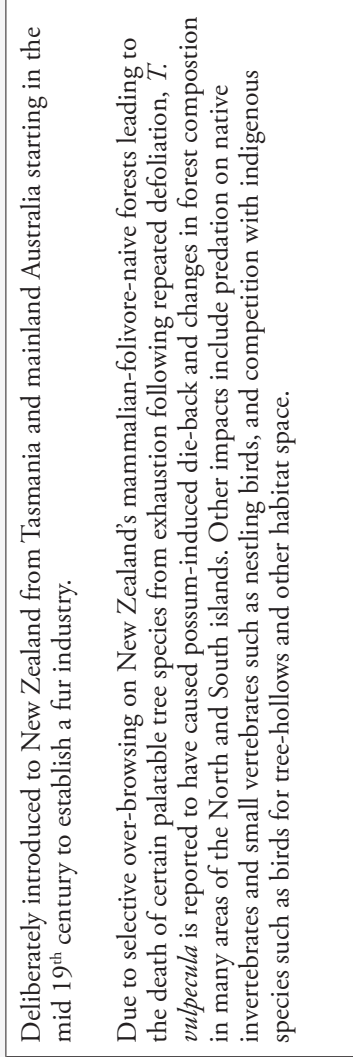 & 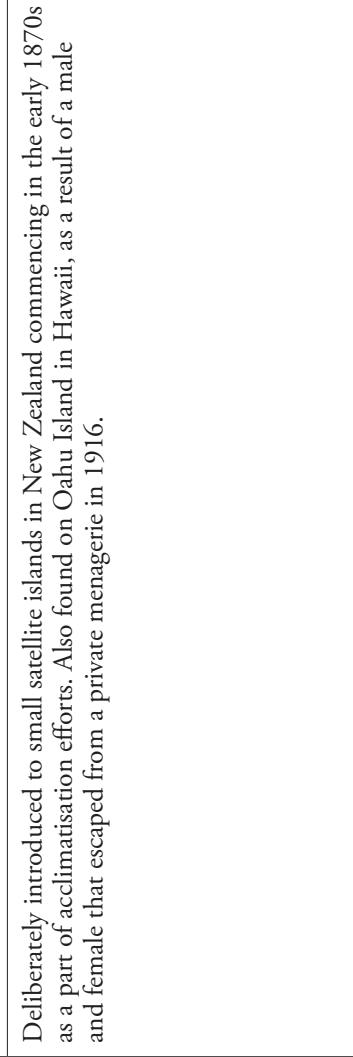 & 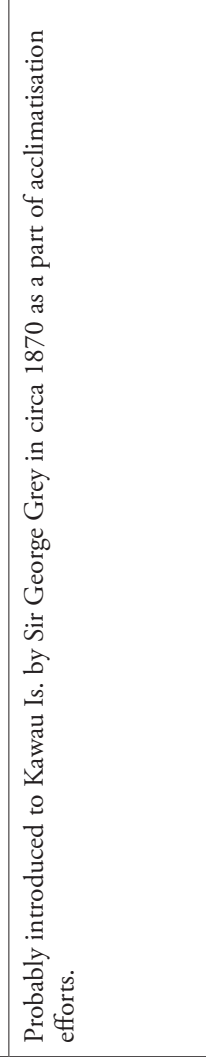 & 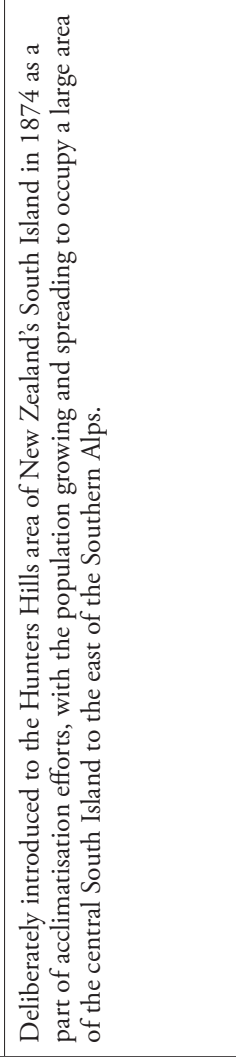 \\
\hline 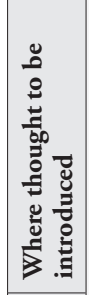 & & 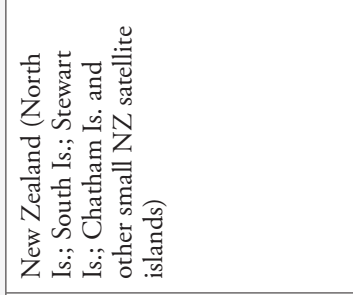 & 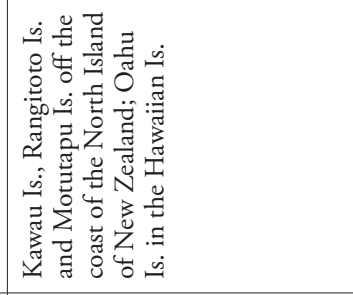 & 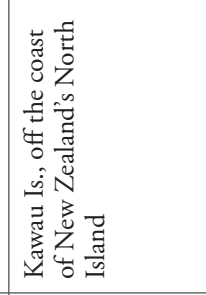 & 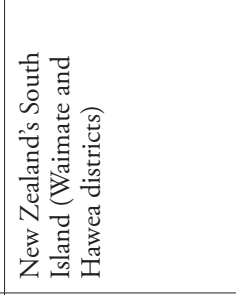 \\
\hline 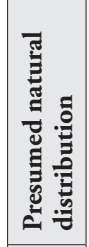 & 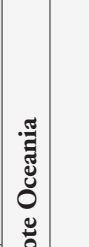 & 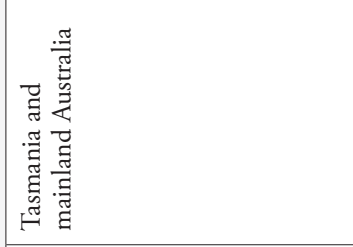 & 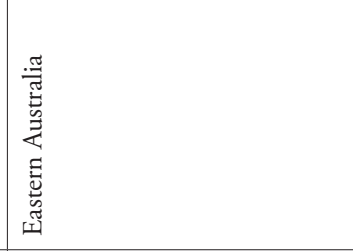 & 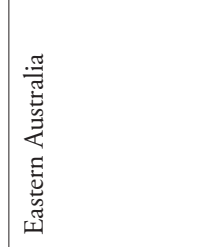 & 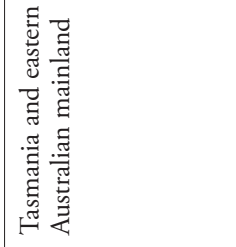 \\
\hline 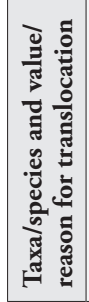 & 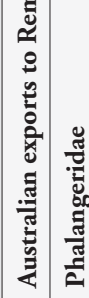 & 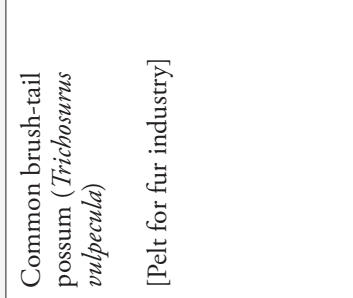 & 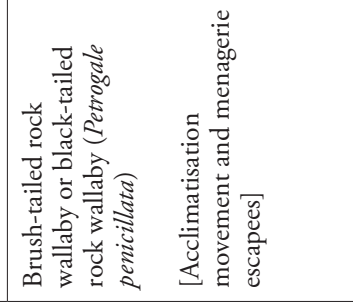 & 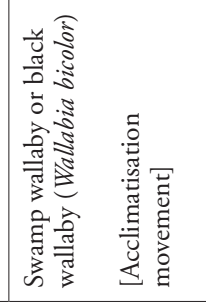 & 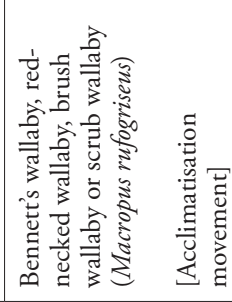 \\
\hline
\end{tabular}




\begin{tabular}{|c|c|c|c|c|c|c|}
\hline 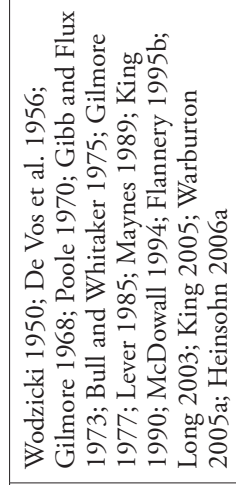 & 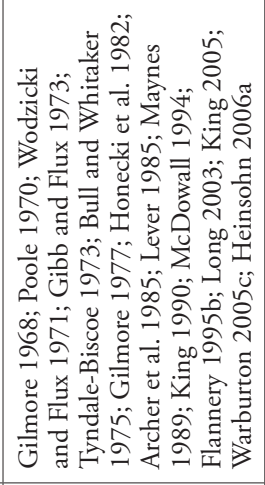 & 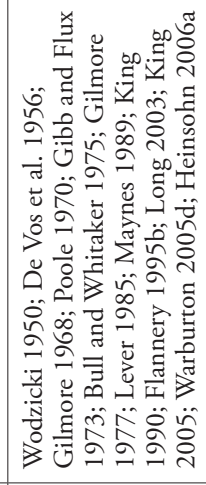 & & 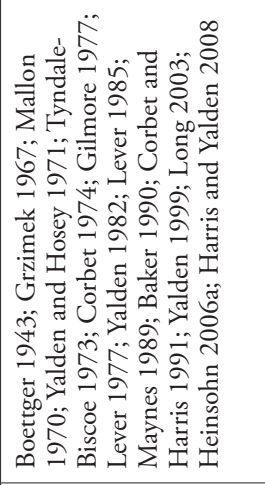 & & 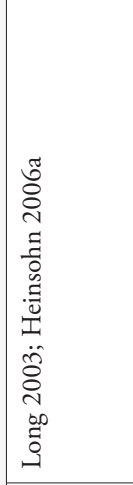 \\
\hline 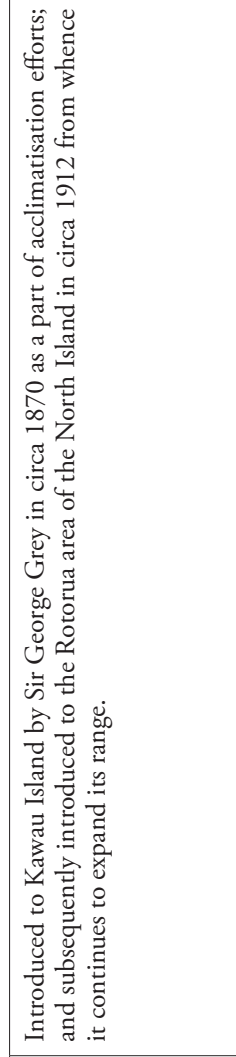 & 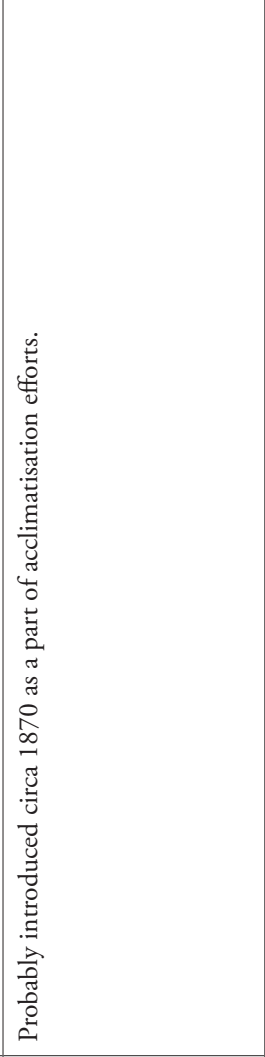 & 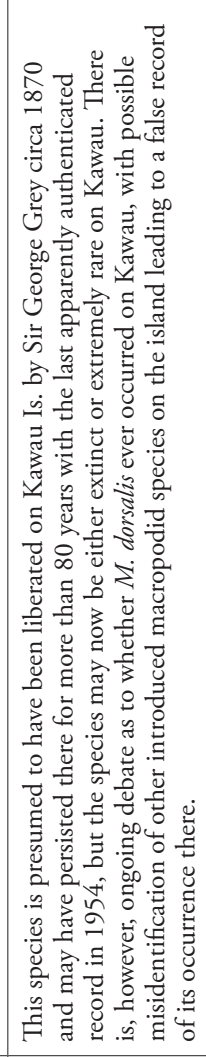 & & 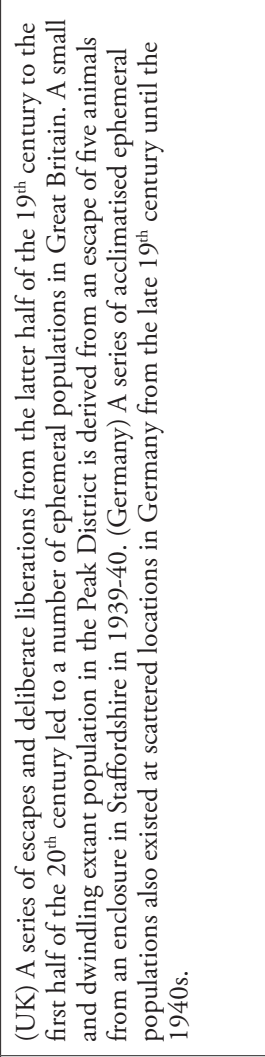 & & 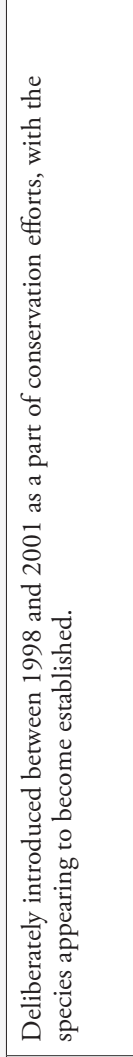 \\
\hline 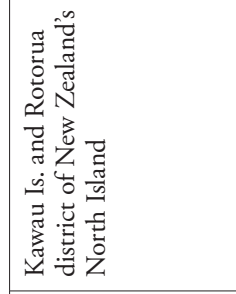 & 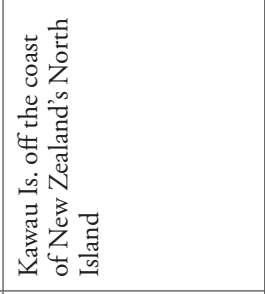 & 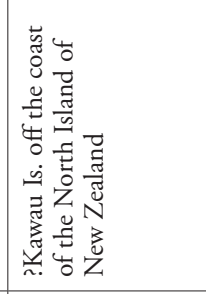 & & 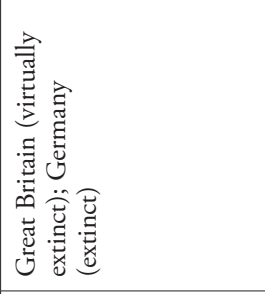 & & 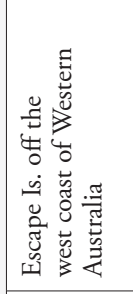 \\
\hline 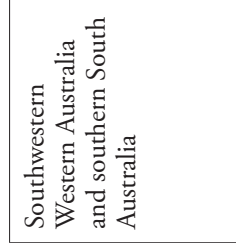 & 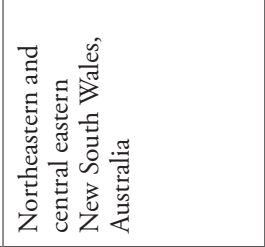 & 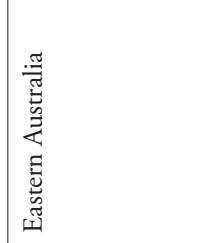 & & 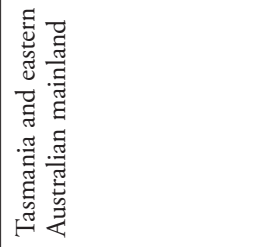 & 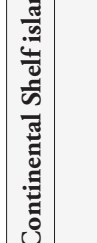 & 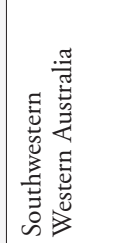 \\
\hline 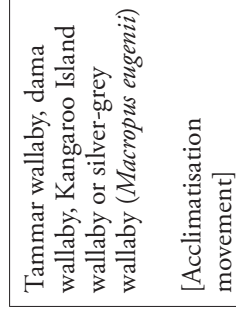 & 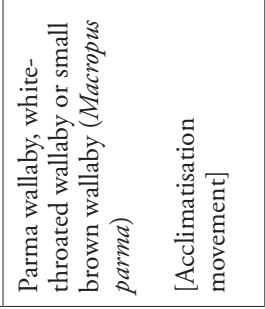 & 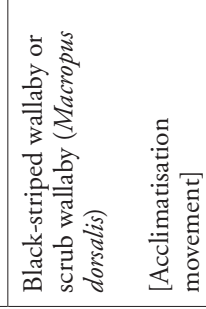 & 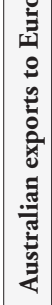 & 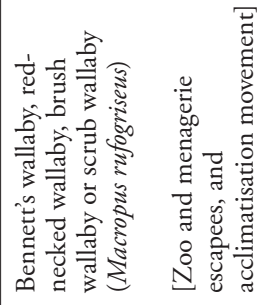 & 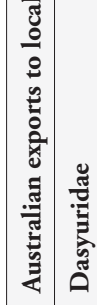 & 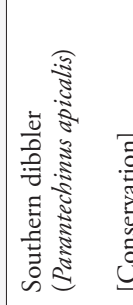 \\
\hline
\end{tabular}




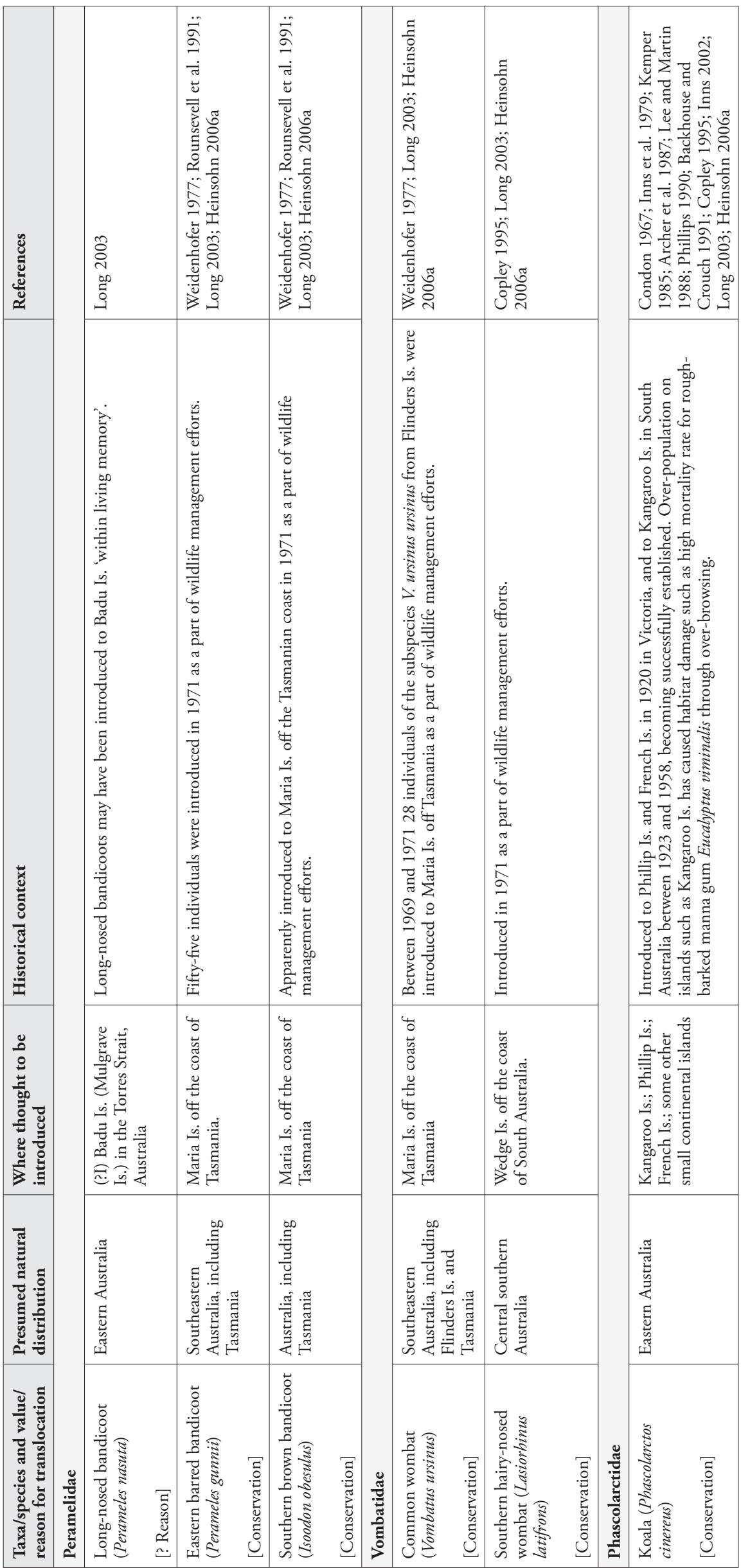




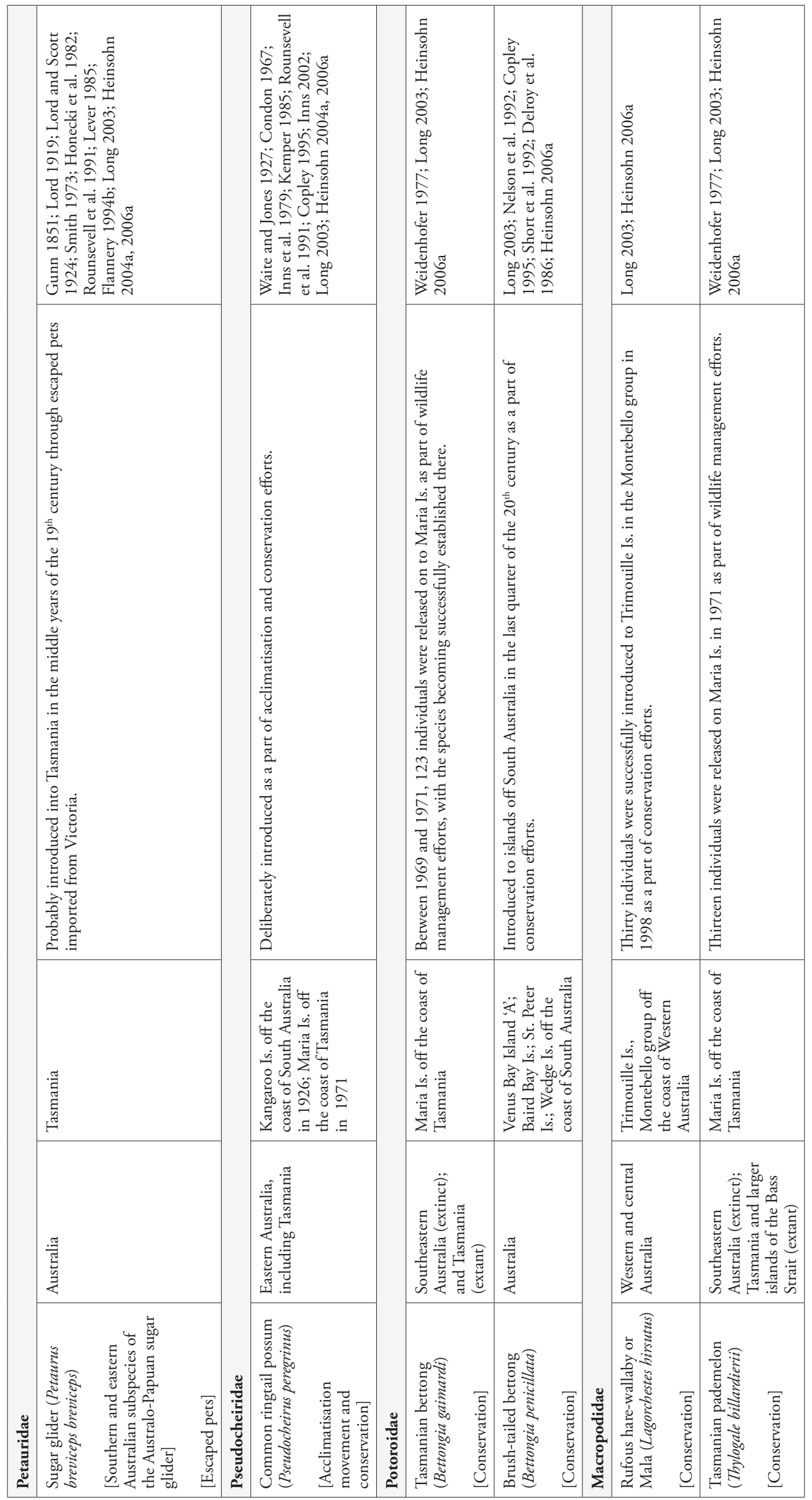




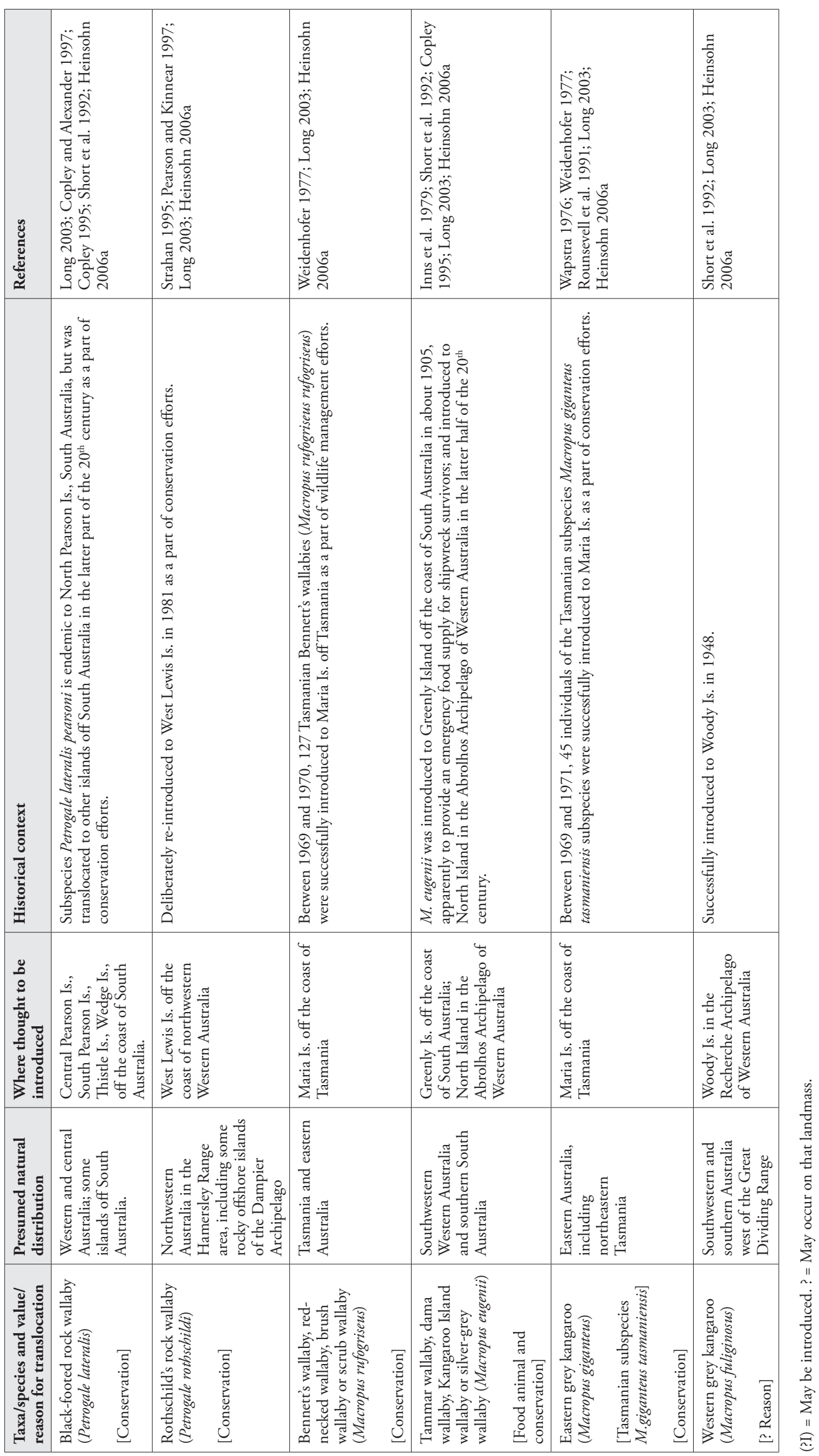




\section{Australian exports}

The translocation of Australian marsupials to new landmasses can be broken down into three categories: (1) species introduced to Europe in recent historic times; (2) species introduced to Pacific islands in Remote Oceania in historically recent times; and (3) species introduced locally to Australia's own continental shelf islands in historically recent times. Currently, there is very little information on possible prehistoric translocation of strictly Australian (as opposed to Australo-Papuan) marsupial species, other than, for example, postulations by McNiven and Hitchcock (2004) based on archaeological and ethnohistorical evidence that Torres Strait Island peoples may have enhanced macropodid populations on some of the Torres Strait islands during insular post-land-bridge Holocene times through introductions or re-introductions of macropodid species, including the Australian common wallaroo Macropus robustus. While this is quite plausible, such postulation currently runs into the problem of clearly distinguishing between natural relictual macropodid populations left over from when the islands were part of the Australo-Papuan Torresian land bridge, and possible subsequently introduced/re-introduced populations. This could potentially be resolved through more extensive archaeological sampling of the area, and molecular systematics analysis of DNA extracted from subfossil bone/teeth and from tissue samples from extant regional macropodid populations.

Only one Australian marsupial species has been successfully introduced to Europe the red-necked wallaby Macropus rufogriseus from eastern and southeastern Australia and Tasmania, with Tasmanian stock principally used. Several small populations were successfully established in Germany and the United Kingdom in the latter half of the $19^{\text {th }}$ century and the first half of the $20^{\text {th }}$ century, through deliberate acclimatisation efforts and escapees from zoos and private menageries. With successful reproductive recruitment, these populations appeared to be naturally viable and able to withstand Palaearctic predators such as foxes and dogs, but for the most part, apart from the impacts of some severe winters, they eventually dwindled because of human predation (especially during the hungry war years in Germany) and the indirect impacts of high human population densities. Today, out of all of these former introduced populations, there are probably only a few animals left, such as in the Peak District of England in the United Kingdom (Long 2003; Heinsohn 2006a; Harris and Yalden 2008).

Seven species of marsupials have been successfully translocated to Pacific islands in Remote Oceania. These include one phalangerid, the common brushtail possum Trichosurus vulpecula, and six macropodids including the swamp wallaby Wallabia bicolor, red-necked wallaby Macropus rufogriseus, tammar wallaby $M$. eugenii, parma wallaby $M$. parma, and black-striped wallaby $M$. dorsalis to New Zealand; and the brushtailed rock wallaby Petrogale penicillata to both New Zealand and Hawaii. Of these, T. vulpecula is now almost ubiquitous in New Zealand, having been introduced to the North Island, South Island, Stewart Island and many satellite islands, including the remote eastern Chatham Islands (pers obs. 2009). Introduction of this folivorous possum began in the mid $19^{\text {th }}$ century to establish a fur industry, with both Tasmanian and mainland Australian stock being imported before use of New Zealandbred stock for later liberations (Thompson 1922; Donne 1924; Wodzicki 1950; Pracy 1962; Montague 2000; Heinsohn 2004a; Cowan 2005; Tyndale-Biscoe 2005). In New Zealand, the possum has become an invasive over-abundant pest species with a significant impact on ecosystems and biodiversity. The principal impact is selective over-browsing on New Zealand's mammalian-folivore-naive forests (there were no native mammalian folivores in New Zealand), leading to the death of certain palatable tree species from exhaustion following repeated defoliation. This is reported to have caused possum-induced die-back and changes in forest composition in many areas of the North and South Islands. For example, species such as rata Metrosideros spp., fuchsia Fuchsia excorticata, titoki Alectryon excelsa and kamahi Weinmannia racemosa have declined in many areas. Possums can also affect plant recruitment in a number of species through consumption of seedlings on the ground or through eating the palatable 
bark on favoured saplings, effectively ring-barking young trees, and this, too, can contribute to changes in plant community composition. Other possum impacts include predation on native invertebrates such as snails and insects and on small vertebrates such as nestling birds, and competition with indigenous species such as birds for tree hollows and other habitat space (King 1984; Montague 2000; Heinsohn 2004a; Cowan 2005; Tyndale-Biscoe 2005; Amanda Baird pers comm. 2009).

In comparison, New Zealand's six macropodids were all introduced as a part of $19^{\text {th }}$ century or early $20^{\text {th }}$ century acclimatisation efforts, and have much more restricted ranges, and limited impacts. Indeed, three species, including W. bicolor, M. parma and M. dorsalis, have been restricted to Kawau Island in the Hauraki Gulf of the North Island since being liberated there by Sir George Grey in c. 1870, and one, $M$. dorsalis, appears to have died out in the mid $20^{\text {th }}$ century after persisting there for 80 years. A further two species, P. penicillata and M. eugenii, were also introduced to Kawau Island by Sir George Grey in c. 1870, where they still persist, but were additionally introduced to other parts of New Zealand. Specifically, in c 1870, P. penicillata was also introduced to Rangitoto and Motutapu Islands in the Hauraki Gulf, where it persisted for about 120 years until being exterminated in the 1990s; while $M$. eugenii was additionally introduced to the Rotorua area of the North Island in c. 1912, where it is now firmly established and from where it continues to expand its range. In contrast, New Zealand's sixth wallaby, M. rufogriseus, was introduced to the Hunters Hills area of the South Island in 1874, and is now firmly established in a considerable area of the central South Island to the east of the Southern Alps. It is the only macropodid in the south, and was never established in northern New Zealand (Wodzicki 1950; Lever 1985; Maynes 1989; Long 2003; King 2005; Warburton 2005a, b, c, d, e, f).

Of the aforementioned Australian macropodids introduced to temperate New Zealand, the brushtailed rock wallaby Petrogale penicillata is now also established on the Hawaiian island of Oahu in tropical Remote Oceania. This occurred as a result of a single male and female pair that escaped from a private menagerie in 1916. A small, apparently viable population persists to this day in steep rocky terrain on Ewa Kalihi in the lower Ko'olau Range on Oahu Island, where it is somewhat contained by geography and habitat (Kramer 1971; Tinker 1980; Lazell 1981; Lazell et al. 1984; Lever 1985; Moulton and Pimm 1986; Tomich 1986; Maynes 1989; Ziegler 2002; Long 2003; Heinsohn 2006a).

Of the approximately 20 Australian marsupial species translocated locally to surrounding continental shelf islands in historically recent times, most were introduced or re-introduced to island reserves and refuges in the $20^{\text {th }}$ century for species management and conservation purposes. These mostly fairly minor translocations include: a carnivorous dasyurid; three species of bandicoot; two wombat species; koalas; sugar gliders; common ringtail possums; two bettong species; a hare wallaby; Tasmanian pademelons; two species of rock wallaby; and four wallabies/kangaroos in genus Macropus (Long 2003; Heinsohn 2004a, 2006a; Van Dyck and Strahan 2008) (see Table 1). Of the above, probably the most significant introduction in terms of the scale of the subsequent biological invasion is the mainland Australian sugar glider Petaurus breviceps to Tasmania in the mid $19^{\text {th }}$ century through escaped pets brought from Victoria. After initial escapes in northern Tasmania, perhaps with some further humanassisted dispersal, it is recorded to have spread across the entire length of the island by the early $20^{\text {th }}$ century, and today $P$. breviceps occupies virtually all areas, other than non-congenial habitats such as parts of the damp southwest region (Gunn 1851; Lord 1919; Lord and Scott 1924; Lever 1985; Rounsevell et al. 1991; Flannery 1994; Long 2003; Heinsohn 2004a; Van Dyck and Strahan 2008).

Curiously, the introduction of the koala Phascolarctos cinereus to Kangaroo Island in South Australia in the 1920s has had some parallels to the impact of the brushtail possum T. vulpecula in New Zealand, in that this fairly large arboreal folivore has become over- 
abundant on the island and is responsible for the death of certain palatable tree species such as rough-barked manna gum Eucalyptus viminalis through over-browsing. Repeated defoliation through excessive browsing by over-abundant koalas eventually causes a significant proportion of palatable trees to die from exhaustion, thus bringing about changes in forest composition (Inns 2002; Heinsohn pers obs. 2008). Kangaroo Island has a second introduced arboreal folivore, the common ringtail possum Pseudocheirus peregrinus, also introduced in the 1920s (Waite and Jones 1927; Copley 1995; Inns 2002; Long 2003; Heinsohn 2004a), and this species may possibly contribute to cumulative browsing pressures on palatable plant species.

\section{New Guinea and Papuan subregion exports}

With an estimated 80 marsupial species, New Guinea, including its fringing Papuan subregion satellite islands, is the world's second major centre for Australidelphian marsupial radiation (after Australia, which has nearly 160 species) (Table 2). Despite having half the number of marsupials, the Papuan subregion is, however, the world's greatest exporter of translocated marsupials to surrounding oceanic archipelagos, with 10 or more of its species suspected to have been exported through long-term human agency (Table 1). Furthermore, nearly all of these postulated translocations, including the export of two peroryctid bandicoots, a petaurid glider, several phalangerid possums and several macropodids, are thought to have occurred in prehistoric times. Several of these postulations regarding prehistoric translocations are based principally on archaeological evidence of sudden appearances of skeletal material in archaeological sequences, while other postulations, often regarding areas where little archaeological sampling has occurred, are based on broader ethnozoological and biogeographic contextual analysis, sometimes also including available evidence from the emerging field of molecular systematics.

The oldest postulated marsupial translocation in the region, based on archaeological evidence, is that of the New Guinean northern common cuscus Phalanger orientalis to New Ireland in the outer northwestern arm of the Bismarck Archipelago in Near Oceania at 23,500 BP to 20,000 BP in the late Pleistocene (Flannery and White 1991; Flannery 1993; Spriggs 1997; Leavesley 2005; Summerhayes 2007). This is also the world's oldest recorded anthropogenic animal translocation event, making $P$. orientalis the world's oldest known 'ethnotramp', an animal species dispersed through human agency (as defined in Heinsohn 1997a, 1998a, b, 2001a, 2003, 2004a, 2006a). Furthermore, as P. orientalis may have been translocated through New Britain to New Ireland, populations on the former, if also introduced, may have been translocated at an even earlier date. Other Pleistocene marsupial translocations postulated on the basis of archaeological evidence include the introduction of the New Guinean common spiny bandicoot Echymipera kalubu and the ancestors of the Admiralty cuscus Spilocuscus kraemeri to Manus Island in the northeastern Bismarck Archipelago, possibly at around 13,000 BP in the terminal Pleistocene (Spriggs 1997; Summerhayes 2007). This compares with archaeological evidence for prehistoric Holocene marsupial translocations in Near Oceania which supports postulated introduction of: the New Guinean northern pademelon Thylogale browni to New Ireland between 8400 and 7000 BP; the New Guinean common spotted cuscus Spilocuscus maculatus to the St. Matthias group in the far northern Bismarck Archipelago in the late Holocene; and secondary introductions of $P$. orientalis to Nissan and the Solomon Islands in the middle to upper Holocene (Kirch 1988; Flannery 1995b; Kirch 1997; Spriggs 1997; Summerhayes 2007).

There is also historical and archaeological evidence of further ephemeral (now extinct) introduced T. browni macropodid populations on some of the smaller New Ireland satellites, including Tabar Island, the Lihir group, Tanga Island and Feni Island, and archaeological evidence of possible ephemeral (now extinct) introduced populations of this macropodid on Buka in the North Solomons, and Eloaue Island in the St. Matthias group in the upper 
Holocene (Egloff 1975; Flannery et al. 1988; Flannery 1995b; Spriggs 1997; Heinsohn 2005c; Summerhayes 2007). Combined archaeological, ethnozoological and biogeographic evidence also indicates that another macropodid, the Australo-Papuan agile wallaby Macropus agilis, may have been introduced to its contemporary island range in the continental southeast Papuan islands during mid to late Holocene times (Brass 1956, 1959; Egloff 1979; Maynes 1989; Flannery 1995b; Heinsohn 2003; Long 2003; Heinsohn 2006a).

To the immediate west of New Guinea in the oceanic Moluccas of Wallacea, there has been considerably less archaeological investigation, but limited excavations from places such as Halmahera in the north Moluccas and Gebe, an adjacent oceanic Papuan subregion outlier, indicate that a now extinct, probably introduced, macropodid population of the Papuan brown dorcopsis Dorcopis muelleri occurred on the aforementioned islands in the early and middle Holocene respectively (Flannery et al. 1995; Flannery et al. 1998; Summerhayes 2007). Further archaeological evidence of marsupial translocation comes from Timor in the eastern Lesser Sundas, where more extensive archaeological excavations indicate that the New Guinean northern common cuscus Phalanger orientalis was probably introduced there in the

Table 2. Proportions of introduced marsupials on landmasses in the Indo-Australian Archipelago, Oceania and Europe

\begin{tabular}{|c|c|c|c|}
\hline & Marsupial species & Number introduced & $\begin{array}{l}\text { Percentage } \\
\text { introduced }\end{array}$ \\
\hline \multicolumn{4}{|l|}{ Continental Meganesia } \\
\hline Australia & 158 & 0 & $0 \%$ \\
\hline New Guinea & 80 & 0 & $0 \%$ \\
\hline \multicolumn{4}{|l|}{ Oceanic Wallacea } \\
\hline Halmahera & 2 & ? 1 & $? 50 \%$ \\
\hline Seram & 3 & 2 & $66 \%$ \\
\hline Buru & 2 & 2 & $100 \%$ \\
\hline Kai Is. & 5 & ? 3 to 5 & $\begin{array}{l}? 60 \% \text { to } \\
100 \%\end{array}$ \\
\hline \multicolumn{4}{|l|}{ Sulawesi subregion } \\
\hline (Sulawesi and satellites including Selayar and Peleng) & 4 & 1 & $25 \%$ \\
\hline \multicolumn{4}{|l|}{ Timor } \\
\hline (and Lesser Sundas as a whole) & 1 & 1 & $100 \%$ \\
\hline \multicolumn{4}{|l|}{ Near Oceania } \\
\hline Admiralty Islands & 2 & ? 0 to 2 & ? $0 \%$ to $100 \%$ \\
\hline New Ireland & 3 & 3 & $100 \%$ \\
\hline New Britain & $? 6$ & ? 3 to 6 & $\begin{array}{l}\text { ? } 50 \% \text { to } \\
100 \%\end{array}$ \\
\hline Umboi & 4 & ? 3 to 4 & $\begin{array}{l}\text { ? } 75 \% \text { to } \\
100 \%\end{array}$ \\
\hline Solomon Is. & 1 & 1 & $100 \%$ \\
\hline \multicolumn{4}{|l|}{ Remote Oceania } \\
\hline New Zealand & 6 & 6 & $100 \%$ \\
\hline Hawaiian Is. & 1 & 1 & $100 \%$ \\
\hline \multicolumn{4}{|l|}{ European Continental islands } \\
\hline British Isles & 1 & 1 & $100 \%$ \\
\hline
\end{tabular}

References: Tomich 1986; Whitten et al. 1987; Corbet and Hill 1992; Flannery 1994b; Flannery 1995a, b; Monk et al. 1997; Heinsohn 2001a, 2002a, b, c, 2003, 2004a, b, 2005a, b, c, 2006a; Ziegler 2002; Long 2003; Helgen and Flannery 2004; King 2005; Nowak 2005; Heinsohn and Hope 2006; Harris and Yalden 2008; Van Dyck and Strahan 2008 
middle Holocene (Glover 1971, 1986; Flannery 1995b; Bellwood 1997; Monk et al. 1997; Heinsohn 2003; Summerhayes 2007).

Other than palaeontology and archaeology, a further line of evidence for anthropogenic translocation of New Guinea region marsupials is provided by ethnohistorical and contemporary records of live animals being carried around in watercraft, as pets, living-larder food animals, trade commodities and sources of animal products such as decorative pelts, fibre, bone and teeth. While diminutive marsupials such as young sugar gliders Petaurus breviceps are principally kept as pocket pets (pers obs.), other larger marsupials such as bandicoots, cuscuses, and macropodids can provide significant parcels of bush meat, while in some areas spotted cuscuses Spilocuscus spp. in particular are highly valued for their often colourful pelts, which are worn as esteemed body adornments ('bilas' in New Guinea pidgin), with some tree kangaroo Dendrolagus spp. pelts also prized as bilas (pers obs.). Marsupial fur is also valued as a source of traditional fibre used to make products such as woven bilum bags and hats, with cuscuses and some other possums being plucked for this purpose. Young cuscuses including Spilocuscus spp. and Phalanger spp. are also popular pets, although virtually any young marsupial, including wallaby and tree-kangaroo joeys captured during hunting, may be kept for a while as ephemeral pets or live-animal trade commodities and carried about. Any carriage of pets, trade stock, or living-larder captives increases the chance of escapees establishing new populations beyond their natural range, particularly given the flimsy or lessthan-secure state of various cages, baskets, sacks, woven bags and bindings used to restrain captive marsupials (Heinsohn 1997a, 1998a, b, 2001a, 2003, 2004a, b, 2006a, pers obs.).

There are also contemporary and ethnohistorical records of deliberate attempts to introduce various marsupials such as cuscuses and wallabies to faunally depauperate islands as part of a game-enhancement strategy to provide a future source of food and other animal products. This parallels the well-recorded tradition of European sailors, fishermen and whalers who are historically known to have left breeding stock of goats, pigs and fowls on stop-over islands to ensure a future food supply. The author, for example, recorded details of late $20^{\text {th }}$ century attempts by local Melanesians to introduce the common spotted cuscus $S$. maculatus to Djaul Island off New Ireland, and the Admiralty cuscus S. kraemeri to small satellites such as Bipi Island off Manus, while there is also ethnohistorical evidence that local people traditionally kept some of New Ireland's satellite islands deliberately stocked with northern pademelons Thylogale browni, restocking from larger source populations on the adjacent New Ireland mainland (Heinsohn 1998b, 2005c).

A further recorded case of probable deliberate translocation of New Guinea region marsupials during the historical period is that of the northern common cuscus (Phalanger orientalis) being introduced (or re-introduced) to Long Island off the northeast coast of New Guinea some time in the past 300 years. The oral traditions of local people indicate that the island was deliberately restocked with $P$. orientalis, a valued food animal, following a cataclysmic volcanic eruption of Krakatoan magnitude that occurred three centuries ago and destroyed virtually all life (Koopman 1979; Ball and Hughes 1982; Ian Hughes pers comm. 1990). Jared Diamond (as cited by Koopman 1979:3), reporting on the testimonies of the island's inhabitants, considers that this restocking may have happened in the $19^{\text {th }}$ century, from phalangerid sources on Tolokiwa Island to the east. This is subsequently elaborated on in Mayr and Diamond (2001:18): 'Even the name of the person who introduced Phalanger orientalis to Long Island in the 19th century is known: a man called Ailimai.'

There are also historically recorded cases of secondary marsupial introductions in the Bismarck Archipelago that apparently happened as a result of accidental escape of captive marsupials. This underscores the diversity of likely scenarios for the introduction of New Guinea region marsupials to surrounding archipelagos. Thus, while a great many introductions in the prehistoric past may have been deliberate, as a part of game enhancement strategies to 
add to the faunal resources on islands, a proportion of introductions may have occurred as a result of pets, living-larder food animals, captive trade stock, or simply a hunter's live catch (caught in traps, snares or by hand) that escaped captivity on arrival at a destination (Heinsohn 1997a, 1998a, b, 2001a, 2003, 2004a, b, 2006a).

\section{Contemporary anthropogenic spread of Spilocuscus maculatus in the Bismarck Archipelago}

The first recorded translocation of the New Guinean common spotted cuscus $S$. maculatus into the Bismarck Archipelago is its prehistoric introduction to the remote St. Matthias group in the late Holocene, where the animal remains strongly established to this day (Kirch 1988, 1997; Flannery and White 1991; Heinsohn 1998b). A salient historical case of marsupials apparently established on an island through escaped captives is provided by the story of how S. maculatus subsequently made it to New Ireland from sources in the St. Matthias group. Flannery and White (1991:111) were the first to report in any detail on this case:

'Sanila Talevat, a senior man of Madina, related the facts of the introduction of this species as they were known to him: several $S$. maculatus were brought to Kavieng, northern New Ireland, in 1929 from the St. Matthias Group by Australian Government officials (or possibly their Melanesian employees). [The population on the St. Matthias Group itself results from human introduction.] The animals subsequently escaped. They are now found over a large area of northern New Ireland ... Sanila suggests that they had not spread much farther south than the narrowest part of New Ireland, $-60 \mathrm{~km}$ south of Kavieng.' (Flannery and White, 1991:111, reporting on data collected in 1988)

The contemporary and ongoing human-induced spread of S. maculatus provides an illuminating analogy for anthropogenic biological invasions in the past. The author's own spotlighting survey and oral historical investigation of the distribution of $S$. maculatus in New Ireland revealed that by 1990, it had invaded about $40 \mathrm{~km}$ to $50 \mathrm{~km}$ down the long narrow island (Heinsohn 1998b, 2004a, 2006a) (Figure 4). However, even then, there were reports of isolated adventive populations, apparently mostly derived from escaped or liberated pets carried in by boat or motor vehicle, that were beginning to appear at scattered localities beyond the main invasion front, such as one near Pangeifua some $20 \mathrm{~km}$ further south (Heinsohn 1998b, 2004a). By the mid 1990s, an adventive population of $S$. maculatus had been recorded in lower elevations of the Weiten River Valley of far southern New Ireland (Emmons and Kinbag 2001). This far southern record is more than $200 \mathrm{~km}$ to the south of the main invasion frontier, and probably also represents an adventive population established fairly recently through secondary boat or vehicle transport of pets and captives (author's assessment), and no doubt will go on to form a further invasion beachhead, with such anthropogenic secondary invasion beachheads eventually coalescing to speed up the complete colonisation of New Ireland by S. maculatus (Heinsohn 2006a). Indeed, rapid development of oil palm plantations and the spread of logging activities to far corners of New Ireland has probably hastened the spread of $S$. maculatus through greatly increased vehicular and boat traffic and movement of people, including cashed-up workers who buy the animals at markets for use as food or popular status-enhancing pets.

The latest development is that recently translocated adventive populations of $S$. maculatus, probably from introduced sources in adjacent New Ireland, have begun to appear around villages and plantations in northern New Britain (Sebastian Högberg, pers comm. 2009). Thus, the predicted anthropogenic spread of $S$. maculatus from New Ireland to New Britain has already begun. Adventive populations may also be starting to appear on other New Ireland satellites, such as New Hanover (Lavongai). For a reconstruction of the historical invasion 
of New Ireland and some adjacent islands by S. maculatus, see Figure 4 (Heinsohn 1998b, 2004a, 2006a).

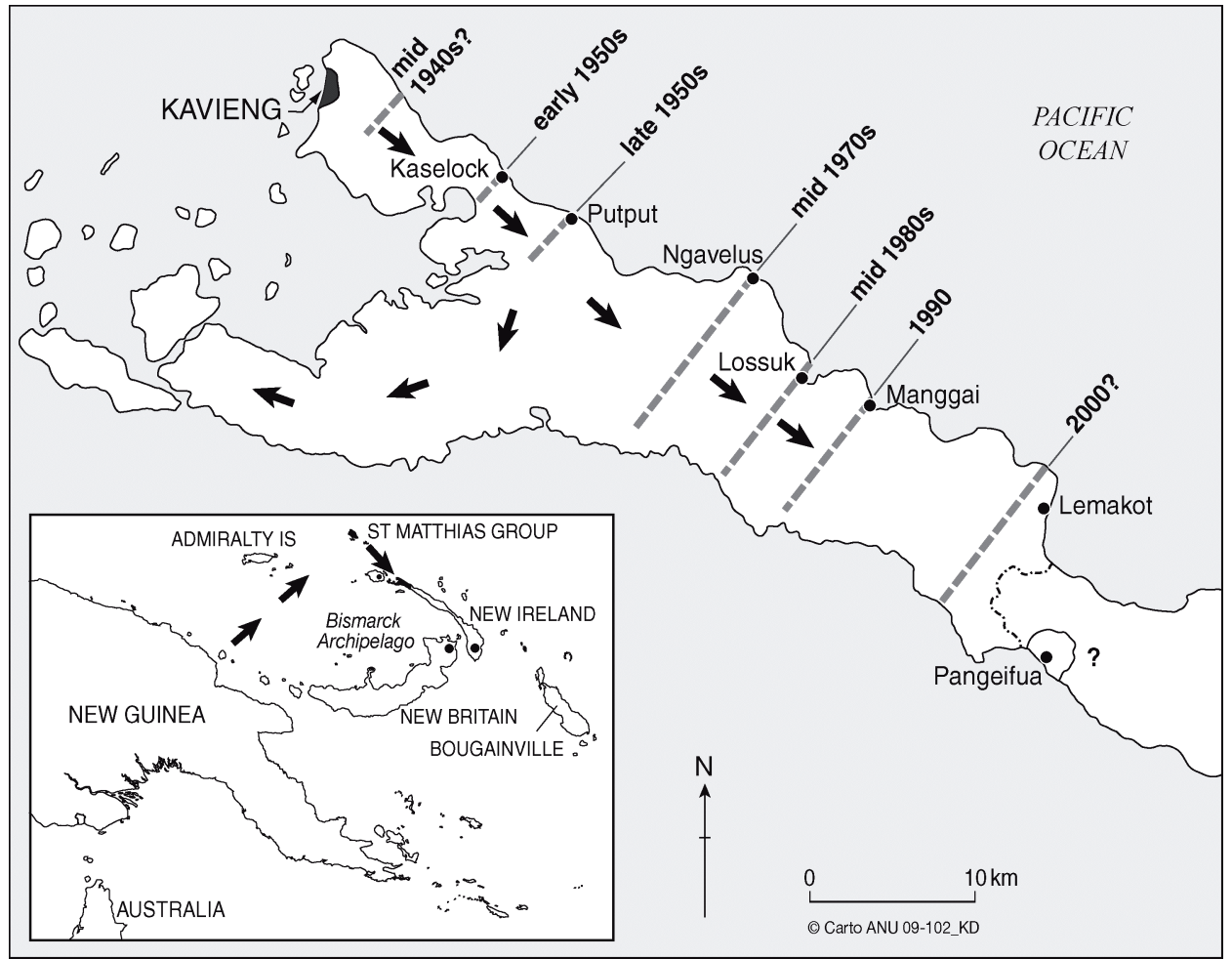

Figure 4. Ongoing biological invasion of the Bismarck Archipelago by the introduced northern New Guinean subspecies of the common spotted cuscus Spilocuscus maculatus maculatus. Inset - This species was prehistorically introduced to the St. Matthias group in the Bismarck Archipelago in the late Holocene, from whence it was subsequently historically introduced to Kavieng at the far northwestern tip of New Ireland in the decade leading up to the commencement of the Second World War. Main map - Reconstruction of the subsequent biological invasion of New Ireland in the latter half of the $20^{\text {th }}$ century. Dot at Pangeifua represents an adventive population beyond the main invasion front. Inset - Dot at the far southern end of New Ireland shows an isolated secondary adventive population of $S$. maculatus recorded at lower elevations in the Weiten River Valley of far southern New Ireland in the mid 1990s more than $200 \mathrm{~km}$ beyond the main invasion front. This is probably due to a secondary introduction of animals brought in from the north by boat or motor vehicle. Dot in northern New Britain represents secondary adventive populations of $S$. maculatus that have recently appeared in and around villages and plantations on that part of the island, probably through boat traffic from adjacent New Ireland. Adventive populations may now also occur on other New Ireland satellites such as New Hanover (Lavongai) marked by a dot (after Heinsohn 2006a)

In New Ireland, it was found that recent biological invasion by a slightly larger and more generalist $S$. maculatus had caused a slight niche contraction in pre-existing prehistorically introduced populations of $P$. orientalis (see Figures 5 and 6). Principally, in broad sympatry with $S$. maculatus within the northwestern New Ireland invasion zone, P. orientalis tended to retreat to core habitats within closed forest, whereas in allopatry beyond the invasion zone, where it was the sole cuscus species, it exhibited a more relaxed niche that also included plantations and some open forest areas. In contrast, the invading $S$. maculatus tended to occupy the full spectrum of closed forest, open forest and plantation, displacing $P$. orientalis from the more marginal plantation and open-forest habitats (Heinsohn 1998a, b, 2004 a, b). It is likely that this pattern will be repeated as $S$. maculatus invades New Britain and other adjacent islands that were once the sole reserve of $P$. orientalis.

The big picture of postulated anthropogenic export of Papuan region marsupials is summarised below. 


\section{Summary of postulated anthropogenic Papuan marsupial exports to surrounding oceanic islands}

Taking all of the above contextual information into account, broad ethnozoological and biogeographic analysis indicates that:

1. Possibly all of the oceanic distribution of the New Guinean northern common cuscus Phalanger orientalis in the Bismarck Archipelago and Solomon Islands in Near Oceania; on Seram, Buru and satellites in the Central Moluccas; on the Kai Islands in the South Moluccas; on Sanana Island in the Sulawesi subregion; and on Timor and its satellites in the Lesser Sundas is due to long-term human agency;

2. Possibly all of the oceanic distribution of the New Guinean common spotted cuscus Spilocuscus maculatus in the St. Matthias group, New Ireland and New Britain in the Bismarck Archipelago; on Seram, Buru and satellites in the Central Moluccas; in the Kai Islands in the South Moluccas; and on far-flung Selayar Island in the Sulawesi subregion is due to long-term human agency;

3. All of the oceanic distribution of the Admiralty cuscus Spilocuscus kraemeri in the Admiralty Islands and other Manus Province Archipelago islands in the Bismarck Archipelago may be due to long-term human agency, with the distinctive specific status possibly being due to human-induced hybridisation and founder effect caused by anthropogenic admixture or introduction of a mixed Spilocuscus spp. founding stock from New Guinea or Papuan subregion sources;

4. The oceanic distribution of the Australo-Papuan sugar glider Petaurus breviceps in the north Moluccas and on some other oceanic New Guinea satellites such as New Britain may be due to long-term human agency;

5. The oceanic distribution of the New Guinean common spiny bandicoot Echymipera kalubu on Manus Island in the Bismarck Archipelago, and on some other oceanic New Guinea satellites such as New Britain, may be due to long-term human agency;

6. The oceanic distribution of the New Guinean rufous spiny bandicoot Echymipera rufescens in the Kai Islands of the south Moluccas may be due to long-term human agency;

7. The oceanic distribution of the New Guinean Huon tree kangaroo Dendrolagus matschiei on Umboi Island, and possible occurrence on New Britain, in the Bismarck Archipelago, is probably due to human agency;

8. The oceanic distribution of the New Guinean northern pademelon Thylogale browni in the Bismarck Archipelago is probably due to long-term human agency;

9. The oceanic distribution of the New Guinean dusky pademelon Thylogale brunii in the Kai Islands of the south Moluccas is probably due to long-term human agency;

10. The oceanic distribution of past populations of the New Guinean/Papuan subregion brown dorcopsis Dorcopsis muelleri in the north Moluccas can probably be attributed to long-term human agency;

11. The distribution of the Australo-Papuan agile wallaby Macropus agilis in the continental southeast Papuan islands is probably due to long-term human agency; and

12. The secondary occurrence of the endemic Woodlark Island cuscus Phalanger lullulae on Alcester Island may be due to long-term human agency (See Table 1). 


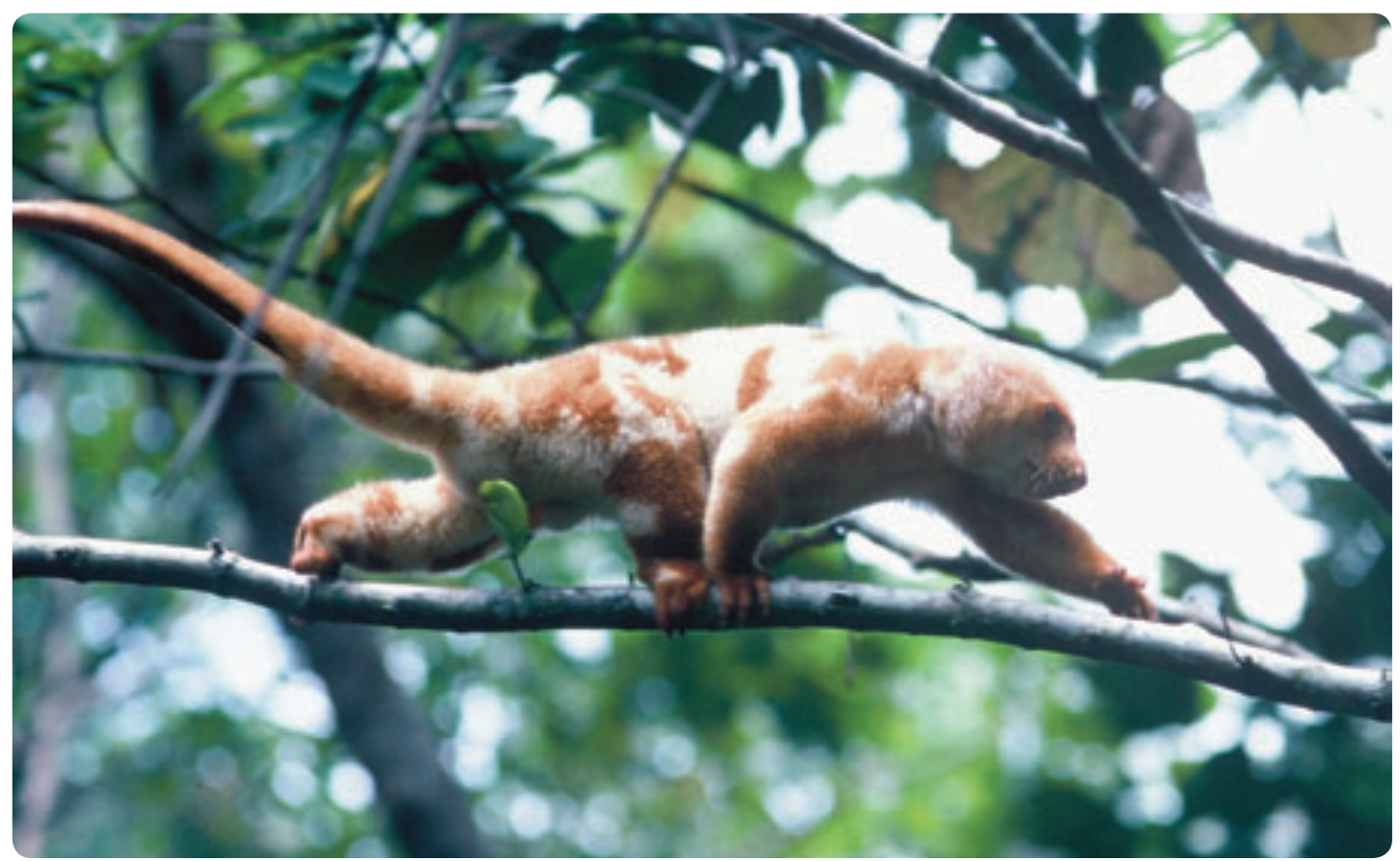

Figure 5. Introduced New Guinean common spotted cuscus Spilocuscus maculatus maculatus invading New Ireland. Photograph by T. E. Heinsohn

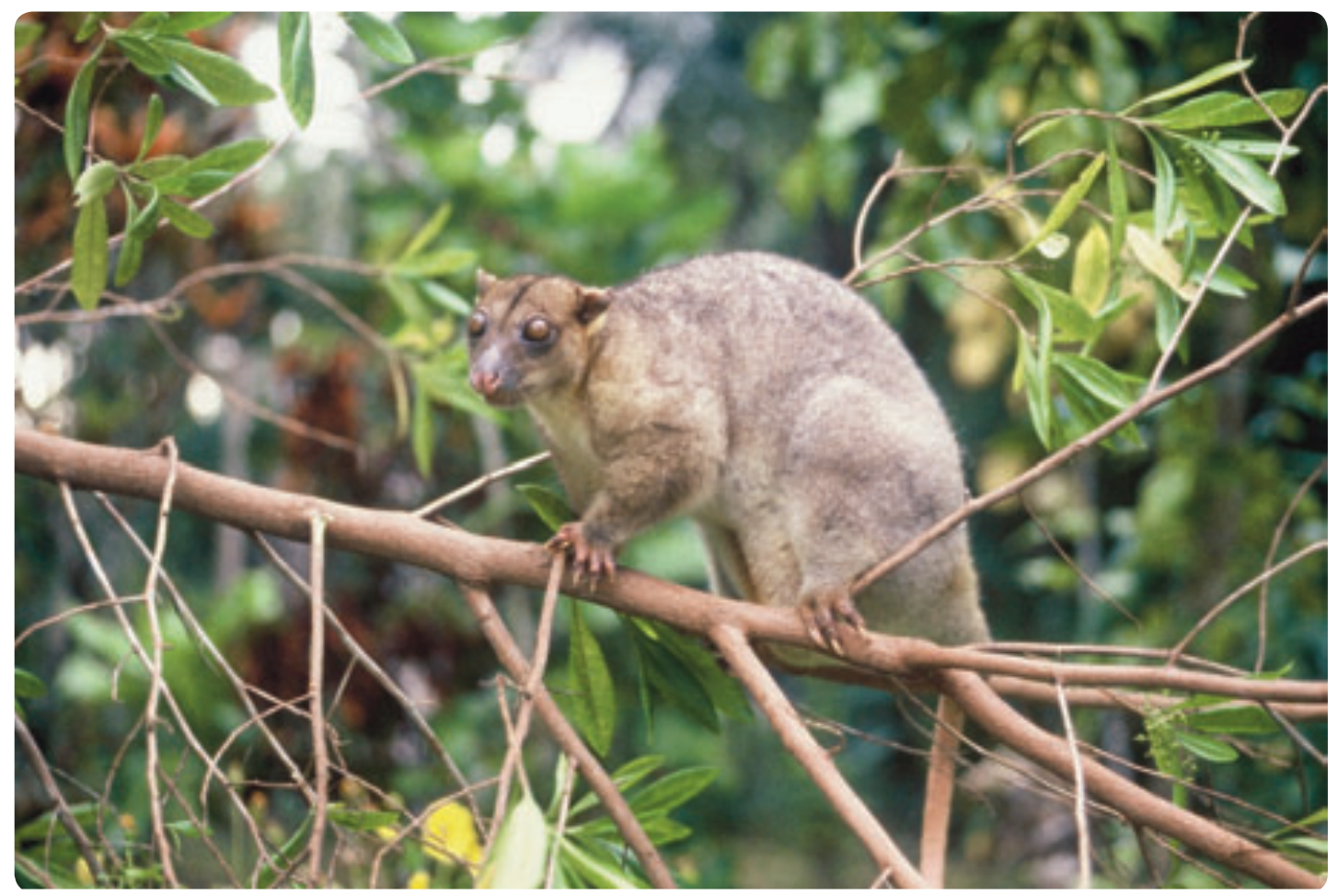

Figure 6. Northern common cuscus Phalanger orientalis in New Ireland, where archaeological evidence indicates that it was probably first introduced between 23,500 and 20,000 years ago in the late Pleistocene. This is the oldest known case of anthropogenic translocation of an animal species making P. orientalis the world's oldest known ethnotramp. Photograph by T. E. Heinsohn 


\section{Wallacean exports}

After Australia and New Guinea, including fringing islands of the Papuan subregion, the third largest centre for Australidelphian marsupial radiations is the oceanic Wallacean islands, which currently have a dozen recorded marsupial species, seven of which are endemic. These seven Wallacean endemics are: (1) three phalangerid possums endemic to the Sulawesi subregion - the Sulawesi bear cuscus Ailurops ursinus, the small Sulawesi cuscus Strigocuscus celebensis, and the Peleng cuscus Strigocuscus pelengensis; (2) three phalangerids endemic to the north Moluccan area, the ornate cuscus Phalanger ornatus, the Obi cuscus Phalanger rothschildi, and the Gebe cuscus Phalanger alexandrae; and (3) one bandicoot, the Ceram bandicoot Rhynchomeles prattorum, endemic to Seram in the central Moluccas. Gebe is a relatively small oceanic island lying near the boundary between the Moluccan and Papuan subregions. Principally because of its avifaunal composition, it is traditionally placed in the latter subregion and treated as an oceanic Papuan outlier (Rand and Gilliard 1967; Coates and Bishop 1997). However, because the Gebe cuscus $P$. alexandrae is closely related to the ornate cuscus $P$. ornatus of adjacent Halmahera in the north Moluccas, it is treated here as a part of the oceanic Wallacean marsupial fauna.

Apart from the Wallacean endemics, as discussed in greater detail above, the other nonendemic marsupials in Wallacea may all have been introduced from New Guinea and its fringing Papuan subregion islands through long-term human agency. These include two probably introduced New Guinean phalangerid possums Phalanger orientalis and Spilocuscus maculatus, one probably introduced Australo-Papuan petaurid glider Petaurus breviceps, one possibly introduced New Guinean bandicoot Echymipera rufescens, and one probably introduced New Guinean macropodid Thylogale brunii (Table 1).

Out of the aforementioned endemic Wallacean marsupials, only one, the Sulawesi bear cuscus Ailurops ursinus, is postulated to have possibly been subjected to human-assisted dispersal beyond its natural range on Sulawesi and some close satellite islands, to Salebabu Island in the remote oceanic Talaud (or 'Talaut') group:

'A. u. melanotis from the Talaut Group is small, and the fur is more profusely tipped with yellow than in other forms. It is provisionally recognised here as a distinct subspecies. However, it is apparently restricted to a single island in the distant Talaut Group, north of Sulawesi, which suggests that it may have been introduced there prehistorically by humans' (Flannery 1994:160)

Indeed, its apparent distinctiveness as a subspecies on Salebabu (as with Spilocuscus kraemeri and Phalanger orientalis breviceps in the northern Melanesian islands of Near Oceania) could possibly be an artefact of long-term human-induced founder effect or anthropogenic allopatric differentiation resulting from thousands of years of isolation on oceanic Salebabu Island following long-term prehistoric introduction there. However, further research, including more extensive zoological surveys, molecular systematics and greater archaeological/palaeontological sampling of regional fossil/subfossil sites, is required to determine whether the outlying Salebabu Island, Talaud group, $A$. ursinus population is relict and due to ancient natural dispersals or an artefact of Quaternary human agency (Heinsohn 2004a, 2006a). Regarding its ethnozoological status, in Sulawesi $A$. ursinus is used for bush meat and sometimes carried about live as a livinglarder trade commodity or pet (pers obs.), thus making it a candidate for possible deliberate or accidental introduction to adjacent islands via liberated or escaped captives. 


\section{Diagnosing the natural marsupial frontier: The problem of ambiguous oceanic marsupial faunas}

In attempting to define the natural marsupial frontier, a line that marks the natural (as opposed to anthropogenic) distributional limits of Australidelphian marsupials, researchers encounter the problem of ambiguous marsupial faunas on certain fringing oceanic islands where there is currently insufficient evidence to determine whether all or some of the marsupial fauna is due to introduction by human agency, or indigenous and due to natural processes such as sweepstakes dispersal on natural rafts. This is because in the absence of historical records or adequate archaeological sampling, prehistorically introduced species, in particular, can mimic recently dispersed naturally occurring species (and vice versa), thus creating cryptogenic populations of unknown status or camouflaged exotic species which appear natural. In the Indo-Australian Archipelago, principally due to insufficient archaeological sampling, cryptogenic marsupial populations occur on New Britain and the Admiralty Islands in the Bismarck Archipelago of Near Oceania, and on Salebabu Island in the Talaud group in the Sulawesi subregion of Wallacea. The ambiguous zoogeographic status of various marsupials on these islands is described in Table 3 .

Table 3. Ambiguous marsupial faunas on oceanic islands at the marsupial frontier (Table 3 continues on pages 160 and 161)

\begin{tabular}{|c|c|c|}
\hline Species & $\begin{array}{l}\text { Putative origins and zoogeographic } \\
\text { context }\end{array}$ & $\begin{array}{l}\text { Zoogeographic and } \\
\text { ethnozoological status }\end{array}$ \\
\hline \multicolumn{3}{|l|}{ Near Oceania } \\
\hline New Britain & $\begin{array}{l}\text { Non-volant mammal fauna is } \\
\text { oceanic and unbalanced. Several } \\
\text { endemic murid rats recorded, but } \\
\text { depauperate compared to New } \\
\text { Guinea mainland (4). }\end{array}$ & \\
\hline \multicolumn{3}{|l|}{ Marsupials } \\
\hline $\begin{array}{l}\text { Common echymipera } \\
\text { Echymipera kalubu } \\
\text { (New Britain) }\end{array}$ & $\begin{array}{l}\text { (a) Possibly arrived from New } \\
\text { Guinea by over-water dispersal on a } \\
\text { natural raft, or } \\
\text { (b) possibly introduced through } \\
\text { long-term human agency. }\end{array}$ & $\begin{array}{l}\text { Cryptogenic - origins unclear on } \\
\text { current evidence. Utilised food and } \\
\text { game animal. Source of bush meat. } \\
(1,2,4,8)\end{array}$ \\
\hline $\begin{array}{l}\text { Sugar glider } \\
\text { Petaurus breviceps } \\
\text { (New Britain) }\end{array}$ & $\begin{array}{l}\text { (a) Possibly arrived from New } \\
\text { Guinea by over-water dispersal on a } \\
\text { natural raft, or } \\
\text { (b) possibly introduced through } \\
\text { long-term human agency. }\end{array}$ & $\begin{array}{l}\text { Cryptogenic-origins unclear on } \\
\text { current evidence. Occasional pet and } \\
\text { eaten as small game animal delicacy. } \\
(1,2,4,8,9)\end{array}$ \\
\hline $\begin{array}{l}\text { Northern common cuscus } \\
\text { Phalanger orientalis } \\
\text { (New Britain) }\end{array}$ & $\begin{array}{l}\text { (a) Possibly arrived from New } \\
\text { Guinea by over-water dispersal on a } \\
\text { natural raft, or } \\
\text { (b) possibly introduced through } \\
\text { long-term human agency. }\end{array}$ & $\begin{array}{l}\text { Cryptogenic - origins unclear } \\
\text { on current evidence. Utilised } \\
\text { ethnotramp. Pet, food, game and } \\
\text { trade animal. Source of animal } \\
\text { products such as bush meat and } \\
\text { bilum fibre. }(1,2,4,8,9)\end{array}$ \\
\hline $\begin{array}{l}\text { Common spotted cuscus } \\
\text { Spilocuscus maculatus maculatus } \\
\text { (New Britain) }\end{array}$ & $\begin{array}{l}\text { This species appears to have been } \\
\text { recently introduced to northern New } \\
\text { Britain in the very late } 20^{\text {th }} \text { century } \\
\text { and/or very early } 21^{\text {st }} \text { century, } \\
\text { probably from adjacent sources in } \\
\text { New Ireland. }\end{array}$ & $\begin{array}{l}\text { Recently introduced species with } \\
\text { adventive populations established. } \\
\text { Utilised ethnotramp. Pet, food, game } \\
\text { and trade animal. Source of animal } \\
\text { products including bush meat, } \\
\text { decorative fur pelts, and bilum fibre. } \\
\text { (11) }\end{array}$ \\
\hline
\end{tabular}




\begin{tabular}{|c|c|c|}
\hline Species & $\begin{array}{l}\text { Putative origins and zoogeographic } \\
\text { context }\end{array}$ & $\begin{array}{l}\text { Zoogeographic and } \\
\text { ethnozoological status }\end{array}$ \\
\hline $\begin{array}{l}\text { ?Admiralty cuscus } \\
\text { ? Spilocuscus kraemeri } \\
\text { (New Britain) } \\
\text { Probably not a part of the New } \\
\text { Britain fauna. }\end{array}$ & $\begin{array}{l}\text { If pets or small adventive } \\
\text { populations of this Admiralty Islands } \\
\text { species do occur anywhere on New } \\
\text { Britain or on any of its small satellite } \\
\text { islands such as Bali Island, Witu } \\
\text { group, then these are likely to be due } \\
\text { to trade animals carried in from the } \\
\text { Admiralty Islands where live animals } \\
\text { are extensively traded for bush meat, } \\
\text { other animal products and pet- } \\
\text { keeping purposes (pers obs.). The } \\
\text { author disagrees with the theory put } \\
\text { forward by Helgen and Flannery } \\
\text { (2005) that } S \text {. kraemeri may be } \\
\text { endemic to New Britain, the original } \\
\text { source, but is cryptic there and } \\
\text { thus not recorded (13). This seems } \\
\text { extremely unlikely as } S \text {. kraemeri is } \\
\text { an adaptable and prominent species, } \\
\text { which, like } S \text {. maculatus, tends to } \\
\text { be easily located during spotlighting } \\
\text { surveys (pers obs.). As such, it is } \\
\text { unlikey to have gone undetected on } \\
\text { New Britain until now. }\end{array}$ & $\begin{array}{l}\text { ?Introduced species if present in } \\
\text { New Britain. Utilised ethnotramp. } \\
\text { Pet, food, game and trade animal. } \\
\text { Source of animal products including } \\
\text { bush meat, decorative fur pelts, and } \\
\text { bilum fibre. }\end{array}$ \\
\hline $\begin{array}{l}\text { Northern pademelon } \\
\text { Thylogale browni } \\
\text { (New Britain) }\end{array}$ & $\begin{array}{l}\text { Probably introduced from New } \\
\text { Guinea through long-term human } \\
\text { agency (as this species is not a likely } \\
\text { candidate for rafting, floating or } \\
\text { swimming). }\end{array}$ & $\begin{array}{l}\text { Prehistorically introduced species. } \\
\text { Utilised ethnotramp. Food, game } \\
\text { and trade animal, and occasional pet. } \\
\text { Source of bush meat. }(1,2,4,8,10)\end{array}$ \\
\hline $\begin{array}{l}\text { Tree-kangaroo } \\
\text { Dendrolagus matschiei } \\
\text { (New Britain) }\end{array}$ & $\begin{array}{l}\text { Probably introduced from New } \\
\text { Guinea through human agency, } \\
\text { possibly from secondary introduced } \\
\text { sources on Umboi Island (as this } \\
\text { relatively large marsupial is not a } \\
\text { likely candidate for rafting, floating } \\
\text { or swimming). }\end{array}$ & $\begin{array}{l}\text { ?Introduced species. Traditional } \\
\text { source of bushm eat and pelts. } \\
\text { Juveniles kept as occasional pets. } \\
(5,7)\end{array}$ \\
\hline Admiralty Islands & $\begin{array}{l}\text { Non-volant mammal fauna is } \\
\text { oceanic and depauperate. One } \\
\text { endemic murid rat recorded ( } 4 \text { ). }\end{array}$ & \\
\hline \multicolumn{3}{|l|}{ Marsupials } \\
\hline $\begin{array}{l}\text { Admiralty cuscus } \\
\text { Spilocuscus kraemeri } \\
\text { (Admiralty Islands) }\end{array}$ & $\begin{array}{l}\text { (a) Ancestral stock possibly arrived } \\
\text { in the Admiralty Islands from New } \\
\text { Guinea by over-water dispersal } \\
\text { on a natural raft, or (b) ancestral } \\
\text { stock was possibly introduced } \\
\text { through long-term human agency. } \\
\text { Distinctiveness may possibly be due } \\
\text { to human-induced founder effect } \\
\text { such as anthropogenic hybridisation } \\
\text { in a mixed founding stock. Helgin } \\
\text { and Flannery (2004) theory of } \\
\text { introduction from undiscovered } \\
\text { populations in New Britain (13) } \\
\text { seems unlikely as this is a highly } \\
\text { visible and adaptable species (pers } \\
\text { obs.) that is unlikely to have } \\
\text { remained undiscovered on New } \\
\text { Britain. }\end{array}$ & $\begin{array}{l}\text { Cryptogenic-origins unclear } \\
\text { on current evidence. Apparently } \\
\text { endemic to Manus Province } \\
\text { Archipelago, but paradoxically } \\
\text { also possibly introduced. Utilised } \\
\text { ethnotramp. Pet, food, game and } \\
\text { trade animal. Source of animal } \\
\text { products including bush meat, } \\
\text { decorative fur pelts and bilum fibre. } \\
(1,2,4,6,8,9) \text {. In Seventh Day } \\
\text { Adventist parts of the Admiralty } \\
\text { Islands where there is reduced } \\
\text { hunting pressure, the species is } \\
\text { reported to become overabundant } \\
\text { and become a minor pest in food } \\
\text { gardens. (12) }\end{array}$ \\
\hline $\begin{array}{l}\text { Common echymipera } \\
\text { Echymipera kalubu } \\
\text { (Admiralty Islands) }\end{array}$ & $\begin{array}{l}\text { (a) Possibly arrived from New } \\
\text { Guinea by over-water dispersal on } \\
\text { a natural raft, or (b) species was } \\
\text { possibly introduced through long- } \\
\text { term human agency. }\end{array}$ & $\begin{array}{l}\text { Cryptogenic - origins unclear on } \\
\text { current evidence. Utilised food and } \\
\text { game animal. Source of bush meat. } \\
(1,2,4,8)\end{array}$ \\
\hline
\end{tabular}




\begin{tabular}{|c|c|c|}
\hline Species & $\begin{array}{l}\text { Putative origins and zoogeographic } \\
\text { context }\end{array}$ & $\begin{array}{l}\text { Zoogeographic and } \\
\text { ethnozoological status }\end{array}$ \\
\hline \multicolumn{3}{|l|}{ Sulawesi Subregion } \\
\hline Talaud Islands & $\begin{array}{l}\text { Non-volant mammal fauna is } \\
\text { oceanic and depauperate. Two } \\
\text { endemic murid rats recorded. (4) }\end{array}$ & \\
\hline \multicolumn{3}{|l|}{ Marsupials } \\
\hline $\begin{array}{l}\text { Sulawesi bear cuscus } \\
\text { Ailurops ursinus melanotis } \\
\text { (Salebabu Island, Talaud Group) }\end{array}$ & $\begin{array}{l}\text { (a) Ancestral stock may have arrived } \\
\text { from Sulawesi or one of its near } \\
\text { satellites by over-water dispersal } \\
\text { on a natural raft, or (b) possibly } \\
\text { introduced to Talaud Islands through } \\
\text { long-term human agency. }\end{array}$ & $\begin{array}{l}\text { Cryptogenic - origins unclear on } \\
\text { current evidence. Utilised food and } \\
\text { game animal. Occasional pet and } \\
\text { sometimes traded. }(1,2,3,4,8,9)\end{array}$ \\
\hline
\end{tabular}

Sources: (1) Tate et al. 1945; (2) Laurie and Hill 1954; (3) Corbet and Hill 1992; (4) Flannery 1995b; (5) Flannery et al. 1996; (6) Helgen and Flannery 2004; (7) Martin 2005; (8) Heinsohn 1998a, 2003, 2006a; (9) Heinsohn 2004a, 2005b; (10) Heinsohn 2005c; (11) Sebastian Högberg, pers comm. 2009; (12) Heinsohn 1998b, 2004a; (13) Helgen and Flannery 2004.

Thus the marsupial fauna of the Talaud group, consisting of a single species $A$. ursinus, may be wholly introduced or wholly natural, while the marsupial fauna of the Admiralty Islands, comprised of two species S. kraemeri and E. kalubu, may be wholly introduced, 50\% introduced, or wholly natural. New Britain, with up to seven, but probably six recorded species, has a marsupial fauna that may be wholly introduced or partially introduced, but not wholly natural, as the most recent introduction, that of $S$. maculatus, is historically recorded. In contrast to ambiguous New Britain, where there has been a lack of zooarchaeological sampling at appropriate sites, the marsupial fauna of neighbouring New Ireland, due to thorough archaeological sampling and historical records, is known to be wholly introduced (Flannery and White 1991; Flannery 1995b; Spriggs 1997; Heinsohn 1998b; Summerhayes 2007).

However, given that all of the marsupial species occurring in the Bismarck Archipelago are utilised or traded ethnotramp species (Heinsohn 2003, 2004a), with even the diminutive sugar glider Petaurus breviceps kept as a pocket pet, and given the lack of stochastic arrival of other nonethnotramp marsupials such as pseudocheirids and dasyurids by sweepstakes dispersal during the late Cenozoic, the author considers it quite possible that the entire marsupial population in the archipelago was introduced through long-term human agency. Indeed, given all of the known precedents of marsupial translocation in the Bismarck Archipelago and the Solomon Islands, an application of the Occam's razor principle of looking for the simplest explanation could support attribution of the entire marsupial population of Near Oceania to long-term human agency, with the same principle also applied to the outlying $A$. ursinus population in the remote and oceanic Talaud Group. This leads to the author's proposed line of actual natural marsupial distributional limits marked by the bold broken line in Figure 7 . This contrasts with Figure 8 which depicts the contemporary line of Australasian marsupial distributional limits when one takes into account all natural and introduced marsupial populations in the region. This represents a considerable anthropogenic expansion of the marsupial frontier into Near Oceania, Remote Oceania and southern Wallacea.

On the basis of the Occam's razor principle of parsimonious explanation and some ethnozoological and ecological considerations, the plausibility of the recent Helgen and Flannery (2004) radical hypothesis regarding possible New Britain origins for the Admiralty cuscus Spilocuscus kraemeri in the Bismarck Archipelago is questioned below. S. kraemeri is recorded from the Admiralty Islands and some outlying satellites such as the Hermit Islands, the Ninigo group and Wuvulu in the vast oceanic Manus Province Archipelago of Papua New Guinea (Laurie and Hill 1954; Flannery 1994, 1995b; Heinsohn 2004a). The species has the curious status of being apparently endemic to the Manus Province Archipelago, but paradoxically also considered to have been possibly introduced there from unknown sources in the New Guinea region (Flannery 1994, 1995b). On the basis of limited archaeological 
sampling from the Pamwak site on Manus Island, it is considered that this may have happened in the terminal Pleistocene (Spriggs 1997; Summerhayes 2007). The author has postulated that the apparent distinctiveness of $S$. kraemeri may be due to anthropogenic founder effect and genetic drift which have exaggerated allopatric differentiation since introduction thousands of years ago, and that this founder effect possibly may have involved anthropogenic hybridisation or admixture following introduction of a mixed Spilocuscus spp. founding stock from sources in the New Guinea region (Heinsohn 1997a, 1998a, b, 2003, 2004a, 2006a). A regional precedent for this model is provided by the introduced pigs of New Guinea which may be derived from hybrids of Sus scrofa vittatus and Sus celebensis carried in from sources in the Indonesian Archipelago during the Holocene (Groves 1981; Flannery 1995a). If humans can inadvertently almost create a new taxon with ethnotramp pigs, then why not with ethnotramp phalangerids? A further possibility, however, regarding the origins of $S$. kraemeri in the Admiralty Islands is that it is due to natural waif dispersal of ancestral founding stock from New Guinea or its fringing Papuan subregion islands in the prehistoric past via animals washed out to sea on natural rafts as a result of floods, king tides, storms or tsunamis. However, even if $S$. kraemeri did make it to the Admiralty Islands by natural means, at least part of the animal's distribution within the vast Manus Province Archipelago, such as that on the outlying Hermit Islands, the Ninigo group and Wuvulu, is probably due to human agency, as the species is extensively traded at markets in that province, and to this day continues to be carried about in traditional vine baskets and other cages (pers obs.; Heinsohn 1998a, b, 2003, 2004a, 2006a).

A radical new hypothesis regarding the origins of S. kraemeri in the Admiralty Islands was presented by Helgen and Flannery (2004), who on the basis of two specimens, one bought at a New Britain market and reputed to come from Bali Island in the Witu group of West New Britain and a further museum specimen labelled 'New Britain', proposed that the species differentiated in New Britain becoming an island endemic, and was subsequently introduced to the Admiralty Islands by prehistoric human agency. Furthermore, they proposed that the species may still be in New Britain, but is cryptic there, thus remaining undiscovered and unrecorded on that island or its near satellites (Helgen and Flannery 2004). The author's own view is that the above hypothesis is improbable as it is extremely unlikely that New Britain would have been home to a prominent species such as $S$. kraemeri without it being firmly recorded by science over recent centuries. This is underscored by the fact that in the Admiralty Islands, S. kraemeri (as with S. maculatus in New Ireland) is a highly adaptable animal found in primary and secondary forest habitats as well as spreading into plantations and gardens, with its presence being well known by local villagers and hunters, and other than where locally over-hunted, is also relatively easily detected by biologists with spotlights and head torches (pers obs.; Heinsohn 1998b). Thus, it is extremely unlikely not to have been discovered on New Britain if present there.

It is much more likely that the few specimens of $S$. kraemeri with a New Britain provenance represent animals traded in from the Admiralty Islands. After all, if S. kraemeri can be traded as far as the Wuvulu, Ninigo and Hermit groups far to the west of the main Admiralty Islands, as is well recorded, then one would also consider it quite likely for animals to be traded to the southeast as far as New Britain and satellites such as Bali Island in the Witu group of West New Britain Province, the latter of which is about the same distance from the Admiralty Islands as Wuvulu. Indeed, confusion caused by the uncertain provenance of trade animals or naive acquisition-point labelling of specimens collected from traders is a well-recorded epistemological problem in the interpretation of historical museum systematics collections (as discussed in Heinsohn 2006a).

Helgen and Flannery (2004) do offer a possible explanation for the cryptic nature of putative undiscovered New Britain S. kraemeri populations, such as competitive suppression by local populations of Phalanger orientalis breviceps, making them rare. However, in the 


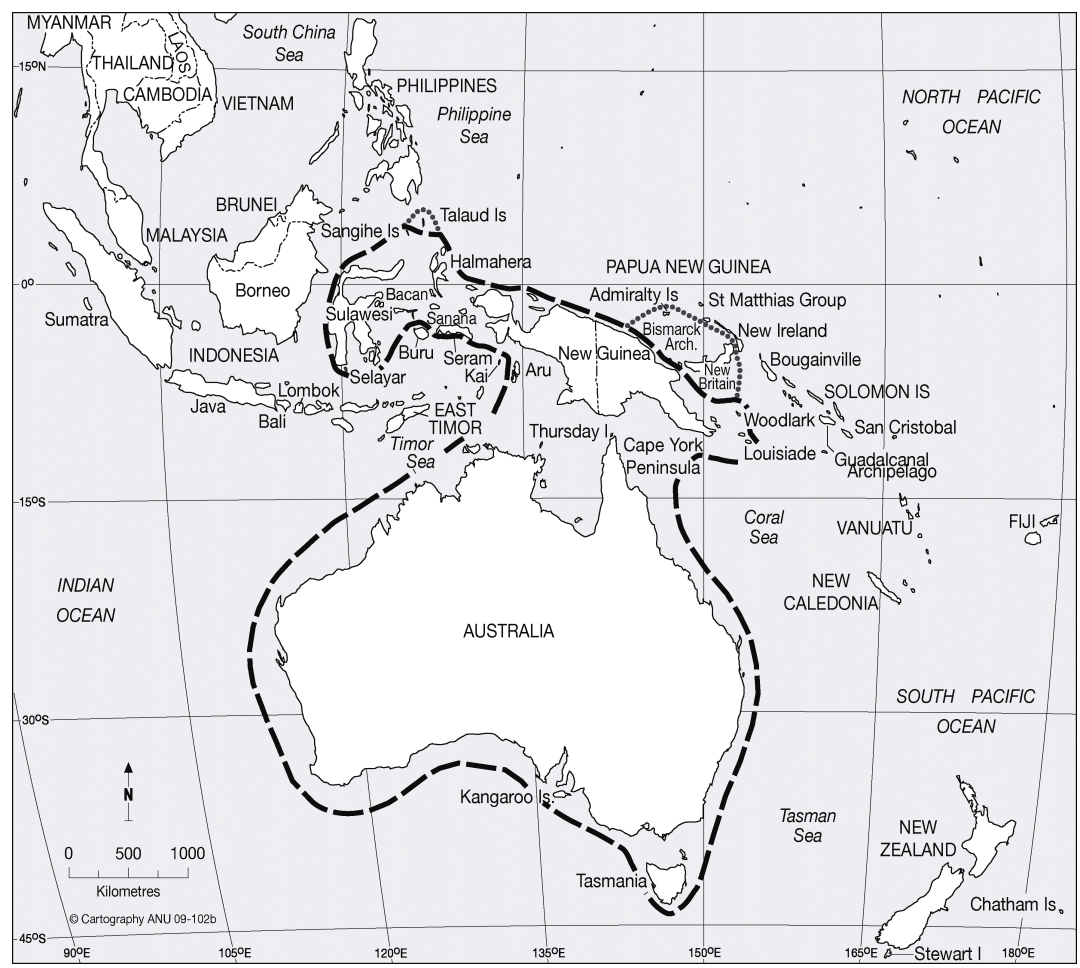

Figure 7. Author's postulated actual natural marsupial distribution when one subtracts probably or possibly introduced marsupial populations (bold dashed line). This represents an older natural marsupial frontier prior to prehistoric and historic human influences on zoogeography. The bold broken line represents the maximum degree to which the natural marsupial frontier retreats if ambiguous marsupial faunas on New Britain, Admiralty Islands and the Talaud Group turn out to be introduced. Fainter dotted line extensions represent the degree to which the natural marsupial frontier expands if ambiguous elements of the New Britain, Admiralty Islands and Talaud marsupial faunas turn out to be naturally occurring through waif dispersal such as on natural rafts (after Heinsohn 2006a)

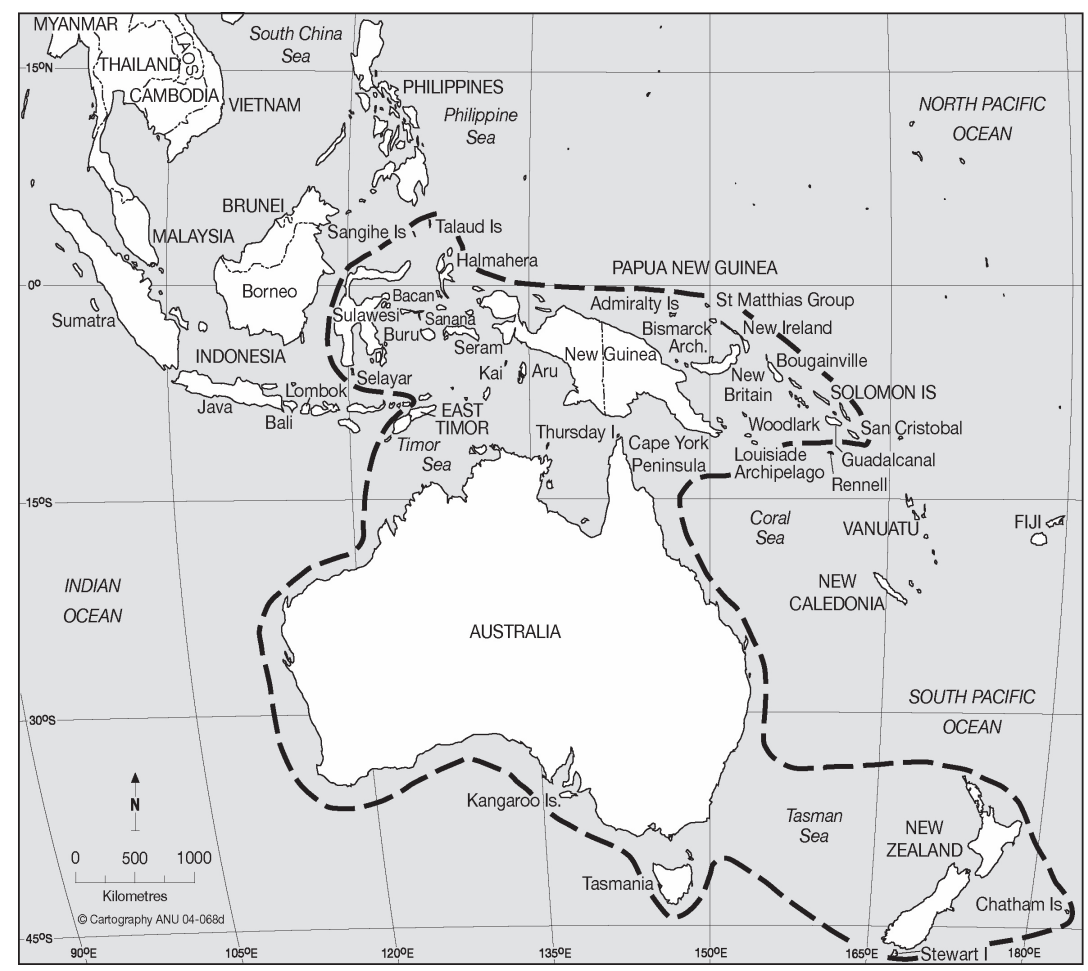

Figure 8. Line of actual marsupial distributions in Australasia taking into account all natural and introduced marsupial populations. This represents the contemporary human-influenced marsupial frontier in Australasia (after Heinsohn 2006a) 
author's own observations of interspecific interactions between sympatric populations of slightly dwarfed island populations of Spilocuscus maculatus maculatus and Phalanger orientalis breviceps in northwestern New Ireland during a six-month field season, it was the larger Spilocuscus that had a competitive suppressing effect on Phalanger, rather than the other way around, with Spilocuscus being generally easier to detect in northwestern New Ireland than Phalanger (Heinsohn 1998b, 2004a, b). As S. kraemeri is only slightly smaller than S. maculatus maculatus, and probably a little larger than island populations of $P$. orientalis breviceps, it is unlikely for $P$. orientalis breviceps to cause competitive suppression of $S$. kraemeri should the two come into sympatric contact. Thus, the Helgen and Flannery (2004) theory is regarded as implausible on ecological and ethnozoological grounds.

Thus two apparent records of S. kraemeri on Bali Island, the Witu group, West New Britain Province, and on the New Britain mainland respectively are most likely due to trade animals carried in from Manus Province. However, this does raise the possibility that adventive populations of $S$. kraemeri derived from escaped or liberated trade animals from Manus Province may have become established in places such as the Witu islands of West New Britain Province. Furthermore, if recently introduced adventive populations of both $S$. maculatus and S. kraemeri are beginning to appear on New Britain or some of its satellite islands, then this may eventually lead to interbreeding and the creation of a new hybrid Spilocuscus population, thus setting off a new evolutionary concatenation in the anthropogenic island biogeography of phalangerids in Near Oceania. Thus, as has probably happened in the past, humans may again be on the verge of creating new taxa through anthropogenic hybridisation.

\section{Discussion and conclusions: Implications of recent recognition of long-term marsupial translocation in the Indo-Australian Archipelago}

As discussed above, in the Indo-Australian Archipelago, up to five out of 12 extant oceanic Wallacean marsupials $(-42 \%)$ may have been introduced from New Guinea or fringing Papuan subregion islands through long-term human agency (the other seven $-58 \%$ being Wallacean endemics). This compares with the oceanic Bismarck Archipelago and Solomon Islands of Near Oceania, where possibly all of the marsupials may have been introduced from New Guinea or Papuan subregion sources. However, this strong long-term anthropogenic effect on Indo-Australian oceanic marsupial faunas has only recently been uncovered. This started with the 1960s archaeological work of Glover $(1971,1986)$ in Timor, who revealed that the island's single marsupial, the New Guinean northern common cuscus Phalanger orientalis, had probably been introduced in the mid Holocene. Following this revelation, came the 1980s and 1990s work of the Lapita Homeland Archaeological Project, which revealed that a whole range of marsupials in Near Oceania (the Bismarck Archipelago and Solomon Islands) had also been prehistorically introduced, some as early as the late Pleistocene (Allen and Gosden 1991; Flannery and White 1991; Kirch 1997; Spriggs 1997; Summerhayes 2007). This exposed the naivety of early marsupial biologists and most of the classic zoogeographers who had failed to imagine that tropical Indo-Australian marsupials, as economically valued commodities (in common with various placental species such as rusa deer Cervus timorensis), might also have been subject to long-term anthropogenic translocation and range expansion (Heinsohn 1997a, 1998a, b, 2001a, 2003, 2006a).

As late as 1977, marsupial biologist Gilmore, for example, in an essay entitled 'The success of marsupials as introduced species', while showing great awareness of historically recent Australidelphian marsupial introductions to the United Kingdom, New Zealand and Hawaii, automatically attributed the occurrence of all other far-flung oceanic populations, such as those in the Solomon Islands to 'natural spread' (Gilmore 1977:169). Furthermore, 
as late as the 1960s, world-renowned zoogeographer Simpson, in an essay entitled 'Historical Zoogeography of Australian Mammals' (Simpson 1961) and in a subsequent book 'The Geography of Evolution' (Simpson 1965), defined his marsupial line, which purported to show the natural distributional limits of Australasian marsupials (see Figure 1). Other than excluding the obviously introduced marsupials in New Zealand and Hawaii, the Simpson Marsupial Line treated all other oceanic marsupial distributions in the Indo-Australian Archipelago and Australasia as natural.

Going further back in time, while classic $19^{\text {th }}$ century zoogeographer Alfred Russel Wallace demonstrated a precocious awareness that various Oriental placental mammals such as Javan rusa deer Cervus timorensis, long-tailed macaque Macaca fascicularis and Malay civet Viverra tangalunga had been translocated into various parts of Wallacea, he demonstrated an almost complete blind spot regarding the possibility of marsupial translocation, assuming all island marsupial distributions to be natural (Wallace 1869; Heinsohn 1997a, 1998b, 2006a). One cannot help but wonder whether, had Wallace recognised that much of the Wallacean marsupial biota was introduced, he would, in addition to recognising the Wallace Line as the eastern limit of complex Oriental continental faunas, have also perceived the current Lydekker's Line as the western limit of complex Australo-Papuan continental faunas. Instead, however, while getting the Wallace Line substantially right, he erroneously viewed the Wallacean islands as vicariant remnants of a western extension of a sunken 'great Pacific continent', thus mistakenly treating oceanic Wallacea as continental in origin (Wallace 1860, 1869, 1876). Furthermore, virtually all of the other classic $19^{\text {th }}$ century zoogeographers, such as Salomon Müller, Philip Lutley Sclater, Thomas Henry Huxley, Andrew Dickson Murray, Max Wilhelm Weber and Richard Lydekker, who proposed various faunal boundary lines demarcating the Asian and Australian faunas (Figure 1) in their various writings, treated all marsupial faunas in the Malay Archipelago as natural (Heinsohn 2006a). Indeed, even by the mid $20^{\text {th }}$ century, the only classic zoogeographer known to have demonstrated faint early awareness that some marsupial populations in Wallacea may have been introduced through long-term human agency was Philip Jackson Darlington, who in his classic tome Zoogeography: The Geographical Distribution of Animals (1957:468) said, 'Whether some of these marsupials may be introduced on some islands I do not know.'

Latter-day recognition of the status of some oceanic marsupials as introduced species also changes society's ecological perceptions of them. They go from being automatically treated as a benevolent natural part of the environment to being viewed as perhaps out-of-place translocated exotics which may have caused an anthropogenic impact. For example, just as the introduced folivorous common brushtail possum Trichosurus vulpecula is recorded to have caused a considerable impact on New Zealand's indigenous forests and wildlife, so to some degree may have another phalangerid possum, the northern common cuscus Phalanger orientalis, when it first arrived in New Ireland 23,500 to 20,000 years ago, or when it and other phalangerids were first introduced to other tropical oceanic Indo-Australian islands through long-term human agency. For example, during ecological field work in New Ireland in 1990, the author did notice some indications of possum impacts on some trees due to combined browsing pressure from introduced populations of both $P$. orientalis and the common spotted cuscus $S$. maculatus, with cuscuses actually observed in the process of defoliating the branches of favoured food trees such as Intsia bijuga (Heinsohn 1997a, 1998b, 2004a, b).

Indeed, both $P$. orientalis and $S$. maculatus, as adaptable and widely introduced ethnotramp possums in Wallacea and Near Oceania, could be viewed as invasive species, which, among other impacts, could potentially threaten the region's island-endemic phalangerids such as the Papuan subregion's restricted Woodlark Island cuscus Phalanger lullulae, or the restricted north Moluccan and Sulawesi subregion phalangerids through interspecific competition. In other instances, the threat may arise from both competition and possible hybridisation, should, for example, the closely related $S$. maculatus be introduced to the island realm of the 
endemic Waigeo Island cuscus Spilocuscus papuensis. Whatever the case, adaptable ethnotramp species such as $P$. orientalis and $S$. maculatus, and possibly also $S$. kraemeri, particularly with the advent of modern rapid transportation in the region such as motor boats and air services and in the absence of effective biosecurity measures, are likely to continue to expand their ranges. S. maculatus, for example, will rapidly invade all of New Ireland, having been subject recently to secondary translocation into the far southern Weiten River Valley (Emmons and Kinbag 2001; Heinsohn 2006a), far beyond the original northern New Ireland invasion frontier (Heinsohn 1998b, 2004a), with new secondary invasion beachheads eventually coalescing until all suitable habitats on New Ireland are occupied and animals spread further afield to other New Ireland satellites such as New Hanover (Lavongai). From New Ireland, $S$. maculatus trade animals and pets will continue to be carried across the St. George's Channel to neighbouring New Britain, where further adventive populations will become established, and these will coalesce eventually into new invasion fronts from whence locally sourced animals will be traded and carried to other parts of New Britain to repeat the whole process of complete invasion of a new landmass. Then New Ireland and New Britain may become launching platforms for the future spread of $S$. maculatus to Bougainville Province and the Solomon Islands, with the species eventually invading much of Near Oceania. Furthermore, a widely traded S. kraemeri from Manus Province may increase its range through anthropogenic translocation to other parts of the Bismarck Archipelago, perhaps even coming into contact with $S$. maculatus in some locations to form new hybrid populations.

In the Lesser Sundas, introduced populations of $P$. orientalis on Timor and some of its satellites, where it is used as a valued game animal sold at markets and kept as a pet (pers obs.), may gradually spread to other adjacent islands, perhaps eventually making their way westwards along the Lesser Sundas chain; while in the Solomon Islands, the species may eventually be spread to some of the last uninvaded islands such as those in far southern Rennell and Bellona Province, or those of far eastern Temotu (Santa Cruz) Province, or perhaps even beyond to Vanuatu. Thus, owing to some highly adaptable ethnotramp species and anthropogenic translocation, the marsupial frontier is likely to expand rather than contract and contribute to the general homogenisation of biotas during this recent era of accelerated anthropogenic impacts that some have dubbed the Homogenocene (Samways 1999) or Anthropocene (Crutzen and Stoermer 2000; Ruddiman 2003).

However, such translocations are not necessarily always deleterious to all aspects of an island's biota. Introduction of $P$. orientalis to the Solomon Islands in the mid to upper Holocene, just as many of that archipelago's large endemic murid rats were in decline or going extinct under human impacts (Flannery and Wickler 1990; Flannery 1995b; Spriggs 1997; Flannery and Roberts 1999), may have allowed a timely prey-switch for the endemic Sanford's eagle Haliaeetus sanfordi and the fearful owl Nesasio solomonensis, both of which are now recorded to habitually prey on the archipelago's introduced cuscuses (Hadden 1981, 2004; Coates 1990; Doughty et al. 1999). Furthermore, even in places such as New Ireland that lacked giant endemic murids, local populations of the white-breasted sea eagle Haliaeetus leucogaster have learned to prey regularly on both $P$. orientalis and $S$. maculatus, which now provide a locally abundant additional source of prey (Heinsohn 2000; Beehler et al. 2001). A similar prey-shift by various raptors may have occurred also in Timor, with the mid-Holocene introduction of $P$. orientalis and recorded upper-Holocene extinction (Glover 1971, 1986) of a whole suite of giant endemic murid rats.

Another observation that highlights the adaptability and potential invasiveness of some marsupials is the fact that some successfully established populations of both phalangerids and macropodids have arisen from very small founding populations. The entire population of brushtailed rock wallabies Petrogale penicillata on Oahu Island, Hawaii, for example, was established from a single pair that escaped in 1916; while the population of red-necked wallabies Macropus rufogriseus that established in the Hunters Hills area of New Zealand's 
South Island is attributed to a single male and two females released in 1874 (Maynes 1989; Warburton 2005b). Similarly, the entire population of New Guinean common spotted cuscus Spilocuscus maculatus in New Ireland, which now occupies a large swath of the $300 \mathrm{~km}$ long island and probably numbers in the tens of thousands, was probably established from only a few individuals, possibly as few as a single pair, or even just a single gravid female or mother with pouch young (Heinsohn 1998b, 2004a, b). Furthermore, in its most far-flung introduced population on Selayar Island in the Sulawesi subregion, $S$. maculatus even manages to coexist with introduced Oriental placental mammals, including scansorial viverids such as the common palm civet Paradoxurus hermaphroditus, arboreal sciurids such as the plantain squirrel Callosciurus notatus and moderately dense human populations in a highly anthropogenic island environment (Heinsohn 2002a, 2004a). Similar adaptability is demonstrated by P. orientalis in Timor, where that species shares that island's significantly anthropogenic environment with the introduced viverid $P$. hermaphroditus and a scansorial cercopithecid monkey, the longtailed macaque Macaca fascicularis (Heinsohn 2004a, 2005a, b).

On high oceanic islands such as Seram, Buru, Timor, New Britain, New Ireland, Bougainville and Guadalcanal, introduced populations of $P$. orientalis in relative competitive release have also demonstrated considerable ecophysiological adaptability by exhibiting a much greater altitudinal range than occurs in their natural continental context on the New Guinea mainland. For example, whereas P. orientalis is found from sea level to $1500 \mathrm{~m}$ in New Guinea where its altitudinal range appears to be restricted by competition with specialised montane cuscuses, on Seram it is recorded to occur right up to the limits of forest, just below the $3020 \mathrm{~m}$ rocky summit of Mount Binaiya, with these higher altitude populations exhibiting thicker coats than their lowland counterparts (Heinsohn 2005a, b; Heinsohn and Hope 2006).

Just as some marsupials have proved highly vulnerable to threatening processes and extinction, others have proved in the right circumstances to be highly adaptable invasive species that as translocated ethnotramps are bringing about an overall expansion of the marsupial frontier. See the contrast between Figure 7 and Figure 8, the first showing the author's postulated line of natural marsupial distributions, compared with the latter depiction of the contemporary greatly expanded anthropogenic marsupial frontier. Marsupials also push some ethnozoological temporal 'frontiers', in that the world's oldest recorded anthropogenic translocation of an animal is that of the New Guinean cuscus P. orientalis to New Ireland in Near Oceania at 23,500 to 20,000 BP. Thus, the world's oldest known ethnotramp species is a humble marsupial that may have been deliberately harnessed for use on oceanic islands as part of an ancient late-Pleistocene game-enhancement production system. Removal of a traditional Eurocentric theoretical blind spot in relation to Australasian mammals reveals that there may be much more to the humble marsupial than meets the eye. They carry a long human history in their pouches.

\section{Acknowledgements}

The author would like to thank local people across the region and the governments of Indonesia, Timor-Leste, Papua New Guinea, the Solomon Islands and New Zealand for their hospitality and for allowing study visits to various parts of their realms. Regional biologists, Quaternary researchers and archaeologists, especially those associated with the pioneering Lapita Homeland Archaeological Project, are collectively thanked for building much of the knowledge upon which this analysis is based. Special thanks goes to the Department of Archaeology and Natural History, RSPAS, ANU, for support of my studies over the years. Geoffrey Hope, Simon Haberle, Matthew Prebble, Janelle Stevenson, Sue O'Connor, Atholl Anderson, Glen Summerhayes, Matthew Spriggs, Peter Bellwood, Colin Groves, Ken Aplin, J. Peter White, Ian Glover, Tim Flannery, Lester Seri, Robin Hide, Chris Tidemann, 
Chris Ballard, Matthew Leavesley, Gerry Maynes, Kay Dancey and Sebastian Högberg are particular names that come to mind for acknowledgement. Special thanks goes to Professor Geoffrey Hope for being a supervisor, mentor and friend over the years. Graffiti in the ANU Geography Department once read, 'Without Geoff this department would be Hopeless.' You have certainly added heart, soul, vision, and a touch of playful wickedness to the departments you have inhabited.

\section{References}

Allen J. and C. Gosden (eds) 1991. Report of the Lapita Homeland Project. Occasional Papers in Prehistory 20. Canberra: Department of Prehistory, Research School of Pacific Studies, the Australian National University.

Allen J., C. Gosden and J.P. White 1989. Human Pleistocene adaptations in the tropical island Pacific: recent evidence from New Ireland, a Greater Australian outlier. Antiquity 63:584-61.

Anthony N. 2001. Small Mammals: An Annotated Checklist. In G. Allez (ed) New Britain Biological Survey, West New Britain Province, Papua New Guinea, pp34-45. Middleton: University of Wisconsin New Britain Biological Survey.

Archer M., T.F. Flannery and G.C. Grigg 1985. The Kangaroo. Sydney: Kevin Weldon.

Archer M., S. Cork, S. Hand, S. Phillips and M. Smith 1987. Koala: Australia's Endearing Marsupial. Sydney: Leonard Cronin/Reed Books.

Backhouse G. and A. Crouch 1991. Koala management in the Western Port region Victoria. In A.K. Lee, K.A. Handasyde and G.D. Sanson (eds) Biology of the Koala, pp313-321. Chipping Norton: Surrey Beatty and Sons..

Baker S.J. 1990. Escaped exotic mammals in Britain. Mammal Review 20(2/3):75-96.

Ball E.E. and I.M. Hughes 1982. Long Island, Papua New Guinea - People, Resources and Culture. Records of the Australian Museum 34(10):463-525.

Beehler B.M., J.P. Angle, D. Gibbs, M. Hedemark and D. Kuro 2001. A Field Survey of Resident Birds of Southern New Ireland. In B.M. Beehler \& L.E. Alonso (eds) Southern New Ireland, Papua New Guinea: A Biodiversity Assessment. RAP (Rapid Assessment Program) Bulletin of Biological Assessment 21, pp61-66. Washington DC: Conservation International.

Bellwood P. 1997. Prehistory of the Indo-Malaysian Archipelago, Revised Edition. Honolulu: University of Hawaii Press.

Black J. (ed.) 1999. Atlas of World History. London: Dorling Kindersley.

Boettger C.R. 1943. Känguruhs in Deutschland in freier Wildbahn. Natur und Volk 73:331-336.

Brass L.J. 1956. Results of the Archbold Expeditions. No. 75. Summary of the Fourth Archbold Expedition to New Guinea (1953). Bulletin of the American Museum of Natural History 111(2):77-152.

Brass L.J. 1959. Results of the Archbold Expeditions. No. 79. Summary of the Fifth Archbold Expedition to New Guinea (1956-1957). Bulletin of the American Museum of Natural History 118(1):1-70.

Bull P.C. and A.H. Whitaker 1975. The Amphibians, Reptiles, Birds and Mammals. In G. Kuschel (ed) Biogeography and Ecology in New Zealand, pp231-276. The Hague: W. Junk.

Calaby J. 1984. Forward. In M. Archer and G. Clayton (eds) Vertebrate Zoogeography and Evolution in Australasia: Animals in Space and Time, p. v. Sydney: Hespernian Press.

Carlton J.T., 1996. Biological invasions and cryptogenic species. Ecology 77(6):1653-1655. 
Carter T.D., J.E. Hill and G.H.H. Tate 1945. Mammals of the Pacific World. New York: Macmillan.

Chappell J. 1987. Late Quaternary sea-level changes in the Australian region. In M.J. Tooley and I. Shennan (eds) Sea-level Changes, pp296-331. Oxford: Basil Blackwell.

Chappell J. and N.J. Shackleton 1986. Oxygen isoptopes and sea level. Nature 324:137-140.

Coates B.J. 1990. The Birds of Papua New Guinea, Including the Bismarck Archipelago and Bougainville. Volumes $1 \& 2$. Alderley: Dove Publications.

Coates B.J. and K.D. Bishop 1997. A Guide to the Birds of Wallacea: Sulawesi, The Moluccas and Lesser Sunda Islands, Indonesia. Alderley: Dove Publications.

Coates B.J. and W.S. Peckover 2001. Birds of New Guinea and the Bismarck Archipelago: A Photographic Guide. Alderley: Dove Publications.

Condon H.T. 1967. Kangaroo Island and its Vertebrate Land Fauna. Australian Natural History 15(12):409-412.

Copley P.B. 1995. Translocations of native vertebrates in South Australia: a review. In M. Serena (ed) Reintroduction Biology of Australian and New Zealand Fauna, pp35-42. Chipping Norton: Surrey Beatty and Sons.

Copley P.B. and P.J. Alexander 1997. Overview of the status of rock-wallabies in South Australia. Australian Mammalogy 19(2):153-162.

Corbet G.B. 1974. The Distribution of Mammals in Historic Time. In D.L. Hawksworth (ed) The Changing Flora and Fauna of Britain, pp179-202. London: Academic Press.

Corbet G.B. and S. Harris (eds) 1991. The Handbook of British Mammals. Third Edition. Oxford: Blackwell Scientific Publications.

Corbet G.B. and J.E. Hill 1992. The Mammals of the Indomalayan Region: A Systematic Review. Oxford: Natural History Museum Publications / Oxford University Press.

Cowan P.E. 1990. Brushtail Possum. In C.M. King (ed) The Handbook of New Zealand Mammals, pp68-98. Auckland: Oxford University Press..

Cowan P.E. 2005. Brushtail Possum. In C.M. King (ed) The Handbook of New Zealand Mammals. Second Edition, pp56-80. Melbourne: Oxford University Press.

Cowan P.E. and A. Moeed 1987. Invertebrates in the diet of brushtail possums, Trichosurus vulpecula, in lowland podocarp/broadleaf forest, Orongorongo Valley, Wellington, New Zealand. New Zealand Journal of Zoology 14:163-177.

Crutzen P.J. and E.F. Stoermer 2000. The Anthropocene. Global Change Newsletter 41:17-18.

Darlington P.J. 1957. Zoogeography: The Geographical Distribution of Animals. New York: John Wiley and Sons.

Davidson M.M. 1965. Changes in Wild Mammal Populations in Cantebury. Wellington: New Zealand Forest Service.

Davies M., C.R. Twidale and M.J. Tyler (eds) 2002. Natural History of Kangaroo Island. Adelaide: Royal Society of South Australia.

Dawson T.J. 1995. Kangaroos: Biology of the largest marsupials. Sydney: UNSW Press.

Delroy L.B., J. Earl, I. Radbone, A.C. Robinson and M. Hewett 1986. The Breeding and Re-establishment of the Brush-tailed Bettong, Bettongia penicillata, in South Australia. Australian Wildlife Research 13:387-396.

Derbyshire I.D. (ed) 1993. The Hutchinson Dictionary of World History. Oxford: Helicon.

De Vos A., R.H. Manville and R.G. van Gelder 1956. Introduced Mammals and Their Influence on Native Biota. Zoologica: Scientific Contributions of the New York Zoological Society 41(19):163-194.

Dickman C. 2005. Marsupials of the World: An Introduction. In R.M. Nowak (ed) Walker's Marsupials of the World, pp1-67. Baltimore: The John Hopkins University Press.

Dickman C. and R. Woodford Ganf 2007. A fragile balance: The extraordinary story of Australian Marsupials. Fishermans Bend, Vic.: Craftsman House.

Donne T.E. 1924. The Game Animals of New Zealand. London: John Murray. 
Doughty C., N. Day and A. Plant 1999. Birds of The Solomons, Vanuatu and New Caledonia. London: Christopher Helm / A. and C. Black.

Egloff B.J. 1975. Archaeological investigations in the coastal Madang area and on Eloaue Island of the St. Matthias Group. Records of the Papua New Guinea Public Museum and Art Gallery 5:1-43.

Egloff B.J. 1979. Recent Prehistory in Southeast Papua. Terra Australis 4. Canberra: Department of Prehistory, Research School of Pacific Studies, Australian National University.

Emmons L.H. and F. Kinbag 2001. Survey of Mammals of Southern New Ireland. In B.M. Beehler and L.E. Alonso (eds) Southern New Ireland, Papua New Guinea: A Biodiversity Assessment, RAP (Rapid Assessment Program) Bulletin of Biological Assessment 21, pp6769. Washington DC: Conservation International.

Fairbanks R.G. 1989. A 17,000-year glacio-eustatic sea-level record: influence of glacial melting rates on the Younger Dryas event and deep ocean circulation. Nature 342:637-642.

Flannery T.F. 1990a. Mammals of New Guinea. First Edition. Carina: Robert Brown and Associates.

Flannery T.F. 1992. Taxonomic revision of the Thylogale brunii complex (Macropodidae: Marsupialia) in Melanesia, with description of a new species. Australian Mammalogy 15:7-23.

Flannery T.F. 1993. Moving animals from place to place. In G. Burenhult (ed) The Illustrated History of Humankind Volume 1, p175. San Francisco: Harper.

Flannery T.F. 1994. Possums of the World: A Monograph of the Phalangeroidea. Sydney: Australian Museum/Geo Productions.

Flannery T.F. 1995a. Mammals of New Guinea. Revised and updated edition. Sydney: Australian Museum/Reed Books.

Flannery T.F. 1995b. Mammals of the South-West Pacific and Moluccan Islands. Sydney: Australian Museum/Reed Books.

Flannery T.F. 1997. The fate of empire in low- and high-energy ecosystems. In T. Griffiths and L. Robin (eds) Ecology and Empire: Environmental History of Settler Societies, pp46-59. Melbourne: Melbourne University Press.

Flannery T.F., P. Bellwood, J.P. White, T. Ennis, G. Irwin, K. Schubert and S. Balasubramaniam 1998. Mammals from Holocene Archaeological Deposits on Gebe and Morotai Islands, Northern Moluccas, Indonesia. Australian Mammalogy 20(3):391-400.

Flannery T.F., P. Bellwood, P. White, A. Moore, Boeadi and G. Nitihaminoto 1995. Fossil marsupials (Macropodidae, Peroryctidae) and other mammals of Holocene age from Halmahera, North Moluccas, Indonesia. Alcheringa 19:17-25.

Flannery T.F., P. Kendall and K. Wynn-Moylan 1990. Australia's Vanishing Mammals: Endangered and Extinct Native Species. Sydney: Readers Digest.

Flannery T.F., P.V. Kirch, J. Specht and M. Spriggs 1988. Holocene mammal faunas from archaeological sites in island Melanesia. Archaeology in Oceania 23(3):89-94.

Flannery T.F., R. Martin and A. Szalay 1996. Tree Kangaroos: A Curious Natural History. Melbourne: Reed.

Flannery T.F. and R.G. Roberts 1999. Late Quaternary Extinctions in Australasia: An Overview. In R.D.E. MacPhee (ed) Extinctions in Near Time: Causes, Contexts, and Consequences, pp239-255. New York: Kluwer Academic / Plenum Publishers.

Flannery T.F. and J.P. White 1991. Animal Translocation: Zoogeography of New Ireland Mammals. National Geographic Research and Exploration 7(1):96-113.

Flannery T.F. and S. Wickler 1990. Quaternary Murids (Rodentia: Muridae) from Buka Island, Papua New Guinea, with Descriptions of Two New Species. Australian Mammalogy 13:127-139.

Gibb J.A. and J.E.C. Flux 1973. Mammals. In G.R. Williams (ed) The Natural History of New Zealand: An Ecological Survey, pp334-371. Wellington: Reed. 
Gilmore D.P. 1968. Wallabies in New Zealand. Animals June 1968:62-66.

Gilmore D.P. 1977. The success of marsupials as introduced species. In B. Stonehouse and D. Gilmore (eds) The Biology of Marsupials, pp169-178. Baltimore: University Park Press.

Glover I.C. 1971. Prehistoric Research in Timor. In D.J. Mulvaney and J. Golson (eds) Aboriginal Man and Environment in Australia, pp158-181. Canberra: Australian National University Press.

Glover I.C. 1986. Archaeology in Eastern Timor, 1966-67. Canberra: Department of Prehistory, Research School of Pacific Studies, The Australian National University.

Groves C.P. 1981. Ancestors for the pigs: taxonomy and phylogeny of the genus Sus. Technical Bulletin No.3. Canberra: Department of Prehistory, Research School of Pacific Studies, Australian National University.

Groves C.P. 1984. Of mice and men and pigs in the Indo-Australian Archipelago. Canberra Anthropology 7(1 and 2):1-19.

Grzimek B. 1967. Four-legged Australians: Adventures with the Animals and Men in Australia. London: Collins.

Gunn R.C. 1851. On the Introduction and Naturalization of Petaurus sciureus in Tasmania. Papers and Proceedings of the Royal Society of Van Diemen's Land 1:253-255.

Hadden D. 1981. Birds of the North Solomons. Wau Ecology Handbook No. 8. Wau: Wau Ecology Institute.

Hadden D. 2004. Birds and Bird Lore of Bougainville and the North Solomons. Alderley: Dove Publications.

Haeckel E. 1893. Zur Phylogenie der Australischen Fauna. Denkschriften der MedizinischNaturwissenschaftlichen Gessellschaft zu Jena 4:5.

Hall R. 2001. Cenozoic reconstructions of SE Asia and the SW Pacific: changing patterns of land and sea. In I. Metcalfe, J.M.B. Smith, M. Morwood and I. Davidson (eds) Faunal and Floral Migrations and Evolution in SE Asia-Australasia, pp35-56. Lisse: A.A. Balkema.

Harris S. and D.W. Yalden 2008. Mammals of the British Isles: Handbook, $4^{\text {th }}$ Edition. Southampton: The Mammal Society.

Haq B.U., J. Hardenbol and P.R. Vail 1987. Chronology of Fluctuating Sea Levels Since the Triassic. Science 235:1156-1167.

Heinsohn T.E. 1997a. Phantoms in the foliage: human influences on the rainforests of the New Guinea Archipelago. In J. Dargavel (ed) Australia's Ever-Changing Forests 111: Proceedings of the Third National Conference on Australian Forest History, pp278-295. Canberra: Australian Forest History Society/Centre for Resource and Environmental Studies, Australian National University.

Heinsohn T. E. 1997b. Taz-Hatz: Tasmanian Native Mammal Fur Industry Collection Assessment Report (unpublished research report on the Tasmanian fur industry). Canberra: People and the Environment Section, National Museum of Australia.

Heinsohn T.E. 1998a. Captive Ecology. Nature Australia 26(2):36-43.

Heinsohn T.E. 1998b. The Realm of the Cuscus: Animal Translocation and Biological Invasions East of Wallace's Line. Canberra: Unpublished Master of Science Thesis, Geography Department, School of Resource and Environmental Management, Australian National University.

Heinsohn T.E. 2000. Predation by the White-breasted Sea Eagle Haliaeetus leucogaster on Phalangerid Possums in New Ireland, Papua New Guinea. Emu 100:245-6.

Heinsohn T.E. 2001a. Human influences on vertebrate zoogeography: Animal translocation and biological invasions across and to the east of Wallace's Line. In I. Metcalfe, J.M.B. Smith, M. Morwood and I. Davidson (eds) Faunal and Floral Migrations and Evolution in SE Asia-Australasia, pp153-170.Lisse: A.A. Balkema.

Heinsohn T.E. 2001b. A Giant Among Possums: Sulawesi Bear Cuscus. Nature Australia 26(12):24-31. 
Heinsohn T.E. 2002a. Status of the common spotted cuscus Spilocuscus maculatus and other wild mammals on Selayar Island, Indonesia, with notes on Quaternary faunal turnover. Australian Mammalogy 24(2):199-207.

Heinsohn T.E. 2002b. Observations of probable camouflaging behaviour in a semi-commensal common spotted cuscus Spilocuscus maculatus maculatus (Marsupialia: Phalangeridae) in New Ireland, Papua New Guinea. Australian Mammalogy 24(2):243-245.

Heinsohn T.E. 2002c. Possum extinctions at the marsupial frontier: the status of the northern common cuscus Phalanger orientalis on Santa Ana Island, Makira Province, Solomon Islands. Australian Mammalogy 24(2):247-248.

Heinsohn T.E. 2003. Animal translocation: long-term human influences on the vertebrate zoogeography of Australasia (natural dispersal versus ethnophoresy). Australian Zoologist 32(3):351-376.

Heinsohn T.E. 2004a. Phalangeroids as ethnotramps: A brief history of possums and gliders as introduced species. In R. Goldingay and S.M. Jackson (eds) The Biology of Australian Possums, pp506-526. Sydney: Surrey Beatty and Sons.

Heinsohn T.E. 2004b. Ecological variability in the common spotted cuscus Spilocuscus maculatus in the Australasian Archipelago - a review. iIn R. Goldingay and S.M. Jackson (eds) The Biology of Australian Possums, pp527-538. Sydney, Surrey Beatty and Sons.

Heinsohn T.E. 2005a. Den sites and habitats utilised by the northern common cuscus Phalanger orientalis (Marsupialia: Phalangeridae) in East Timor. Australian Mammalogy 27(1):99-101.

Heinsohn T.E. 2005b. The Cuscus That Fooled Science [Northern common cuscus Phalanger orientalis]. Nature Australia 28(5):26-33.

Heinsohn T.E. 2005c. Wallaby extinctions at the macropodid frontier: Changing status of the northern pademelon Thylogale browni in New Ireland Province, Papua New Guinea. Australian Mammalogy 27(2):175-183.

Heinsohn T.E. 2006a. Secret life of the cuscus and the cassowary: The crypto-anthropogenic factor and zoogeographic interpretation in the Indo-Australian Archipelago and Oceania 1846-2006 (With a guide to introduced terrestrial vertebrates in the region). Canberra: Unpublished PhD thesis, Department of Archaeology and Natural History, Research School of Pacific and Asian Studies, Australian National University.

Heinsohn T.E. 2006b. Spread of the cane toad Bufo marinus to San Cristobal (Makira) Island, Solomon Islands. Australian Zoologist 33(4):474-475.

Heinsohn T.E. 2009. The marsupial frontier: a history of Australasian marsupials as introduced species. Monograph in prep.

Heinsohn T.E. and R.G. Barker 2006. Observations of scavenging carnivory by the common brushtail possum Trichosurus vulpecula on macropodid carcasses in Namadgi National Park, montane Southeastern Australia. Australian Zoologist 33(3):295-296.

Heinsohn T.E. and G.S. Hope 2006. The Torresian Connections: Zoogeography of New Guinea. In J.R. Merrick, M. Archer, G.M. Hickey and M.S.Y. Lee (eds) Evolution and Biogeography of Australasian Vertebrates, pp71-93. Sydney: Auscipub.

Helgen K.M. and T.F. Flannery 2004. Notes on the phalangerid marsupial genus Spilocuscus with description of a new species from Papua. Journal of Mammalogy 85:825-833.

Holmes D. 1993. My Seventy Years on the Chatham Islands. Christchurch: Shoal Bay Press.

Honacki J.H., K.E. Kinman and J.W. Koeppl (eds) 1982. Mammal Species of the World: A Taxonomic and Geographic Reference. Lawrence: The Association of Systematics Collections/Allen Press.

Hope G.S. 1996. Quaternary change and the historical biogeography of Pacific islands. In A. Keast and S.E. Miller (eds) The Origin and Evolution of Pacific Island Biotas, New Guinea to Eastern Polynesia: Patterns and Processes, pp165-190.. Amsterdam: SPB Academic Publishing. 
Inger R.F. and H.K. Voris 2001. The biogeographical relations of the frogs and snakes of Sundaland. Journal of Biogeography 28:863-891.

Inns R.W., P.F. Aitken and J.K. Ling 1979. Mammals. In M.J. Tyler, C.R. Twidale and J.K. Ling (eds) Natural History of Kangaroo Island, pp91-102. Adelaide: Royal Society of South Australia.

Inns R.W. 2002. Terrestrial Mammals. In M. Davies, C.R. Twidale and M.J. Tyler (eds) Natural History of Kangaroo Island, pp74-79. Adelaide: Royal Society of South Australia.

Isern T.D. 2002. Companions, stowaways, imperialists, invaders: Pests and weeds in New Zealand. In E. Pawson and T. Brooking (eds) Environmental Histories of New Zealand, pp233-245. Melbourne: Oxford University Press.

Kemper K. 1985. Mammals. In H.J. Aslin (ed) A List of the Vertebrates of South Australia, pp719. Adelaide: South Australian Department of Environment and Planning.

King C.M. 1984. Immigrant Killers: Introduced predators and the conservation of birds in New Zealand. Auckland: Oxford University Press.

King C.M. (ed.) 1990. The Handbook of New Zealand Mammals. Auckland: Oxford University Press.

King C.M. (ed.) 2005. The Handbook of New Zealand Mammals. Second Edition. Oxford: Oxford University Press.

Kirch P.V. 1988. The Talepakemalai Lapita Site and Oceanic Prehistory. National Geographic Research 4(3):328-242.

Kirch P.V. 1997. The Lapita Peoples: Ancestors of the Oceanic World. Oxford: Blackwell.

Koopman K.F. 1979. Zoogeography of Mammals from Islands Off the Northeastern Coast of New Guinea. American Museum Novitates 2690(2):1-17.

Kramer R.J. 1971. Hawaiian Land Mammals. Rutland: Charles E. Tuttle.

Laurie E.M.O. and J.E. Hill 1954. List of Land Mammals of New Guinea, Celebes and Adjacent Islands 1758-1952. London: British Museum of Natural History.

Lazell J.D. 1980. Kalihi Rock Wallaby of Hawaii. Tiger Paper 7(2):31-32.

Lazell J.D. 1981. Strange Rock Wallabies of Oahu. Explorers Journal 59(2):66-67.

Lazell J.D., T.W. Sutterfield and W.D. Giezentanner 1984. The Population of Rock Wallabies (Genus Petrogale) on Oahu, Hawaii. Biological Conservation 30:99-108.

Leavesley M.G. 2001. Thirty-five thousand years in New Ireland. Paradise 145:45-47.

Leavesley M.G. 2005. Prehistoric Hunting Strategies in New Ireland, Papua New Guinea: The Evidence of the Cuscus (Phalanger orientalis) Remains from Buang Merabak Cave. Asian Perspectives 44(1):207-218.

Leavesley M.G. and J. Chappell 2004. Buang Merabak: additional early radiocarbon evidence of the colonisation of the Bismarck Archipelago, Papua New Guinea. Antiquity 78(301):15 online.

Lee A. and R. Martin 1988. The Koala: A Natural History. Sydney: New South Wales University Press.

Lever C. 1977. The Naturalized Animals of the British Isles. London: Hutchinson.

Lever C. 1985. Naturalized mammals of the world. London: Longman.

Lever C. 1992. They Dined on Eland: The Story of the Acclimatisation Societies. London: Quiller Press.

Liem D.S. 1977. A Preliminary report on the ecosystem assessment and the possible reestablishment of agile wallaby (Macropus agilis) on Goodenough Island, Milne Bay Province. Wildlife in Papua New Guinea 77/22:1-32.

Lilley I. 1986. Prehistoric Exchange in the Vitiaz Strait, Papua New Guinea. Canberra: Unpublished PhD Thesis, Prehistory Department, Australian National University.

Long J.L. 2003. Introduced Mammals of the World: Their History, Distribution and Influence. Melbourne, CSIRO Publishing. 
Lord C.E. 1919. Notes on the Mammals of Tasmania. Papers and Proceedings of the Royal Society of Tasmania for the Year 1918:16-52.

Lord C.E. and H.H. Scott 1924. A Synopsis of the Vertebrate Animals of Tasmania. Hobart: Oldham, Beddome and Meredith.

Low T. 2002. The New Nature: Winners and Losers in Wild Australia. Melbourne: Viking.

Mallon D. 1970. Britain's Wild Wallabies. Animals 13(6):256-257.

Martin R. 2005. Tree-kangaroos of Australia and New Guinea. Melbourne: CSIRO Publishing. Maynes G.M. 1989. Zoogeography of the Macropodoidea. In G. Grigg, P. Jarman and I. Hume (eds) Kangaroos, Wallabies and Rat-kangaroos, 2 Volumes, pp47-66. Chipping Norton: Surrey Beatty \& Sons.

Mayr E. and J. Diamond 2001. The Birds of Northern Melanesia: Speciation, Ecology \& Biogeography. Oxford: Oxford University Press.

McCabe J. 1910. Australia - A Museum of Living Antiquities. The Lone Hand November 1, 1910:38-46.

McDowall R.M. 1994. Gamekeepers for the Nation: The story of New Zealand's acclimatisation societies 1861-1990. Christchurch: Canterbury University Press.

McNiven I.J. and G. Hitchcock 2004. Torres Strait Islander Marine Subsistence Specialisation and Terrestrial Animal Translocation. Memoirs of the Queensland Museum Cultural Heritage Series 3(1):105-162.

Menzies J.I. and J.C. Pernetta 1986. A taxonomic revision of cuscuses allied to Phalanger orientalis (Marsupialia: Phalangeridae). Journal of Zoology, London. Series B. 1(3):551-618.

Monk K.A., Y. de Fretes and G. Reksodiharjo-Lilley 1997. The Ecology of Nusa Tenggara and Maluku. Singapore: Periplus Editions.

Montague T.L. (ed.) 2000. The Brushtail Possum: Biology, Impact and Management of an Introduced Marsupial. Christchurch: Manaaki Whenua Press.

Morwood M. 2009. Hobbits in context: hominin biogeography in island Southeast Asia. 2009 Mulvaney Lecture, Australian National University, 13 May 2009.

Morwood M. and P. Van Oosterzee 2007. The Discovery of the Hobbit: The Scientific Breakthrough that Changed the Face of Human History. Sydney: Random House.

Moulton M.P. and S.L. Pimm 1986. Species Introductions to Hawaii. In H.A. Mooney and J.A. Drake (eds) Ecology of Biological Invasions of North America and Hawaii, pp231-249. New York: Springer-Verlag.

Murphy R.C. 1951. The Impact of Man Upon Nature in New Zealand. Proceedings of the American Philosophical Society 95(6):569-582.

Musser G.G. 1987. The mammals of Sulawesi. pp73-93 in Biogeographical Evolution in the Malay Archipelago, edited by T.C. Whitmore. Oxford: Clarendon Press.

Nelson L.S., R.F. Storr and A.C. Robinson 1992. Plan of Management for the Brush-tailed Bettong Bettongia penicillata Gray, 1837 (Marsupialia, Potoroidae) in South Australia. Adelaide: National Parks and Wildlife Service, Department of Environment and Planning.

Nile R. and C. Clerk 1996. Cultural Atlas of Australia, New Zealand and the South Pacific. Sydney: Readers Digest Press.

Nowak R.M. 2005. Walker's Marsupials of the World. Baltimore: The John Hopkins University Press.

Pearson D.J. and J.E. Kinnear 1997. A review of the distribution, status and conservation of rock-wallabies in Western Australia. Australian Mammalogy 19(2):137-152.

Phillips B. 1990. Koalas: The Little Australians we'd all hate to lose. Canberra: Australian Government Publishing Service.

Poole A.L. 1970. Wild Animals in New Zealand. Wellington: A.H. and A.W. Reed.

Pracy L.T. 1962. Introduction and Liberation of the Opossum (Trichosurus vulpecula) into New Zealand. Wellington: New Zealand Forest Service Information Series No. 45. 
Rand A.L. and E.T. Gilliard 1967. Handbook of New Guinea Birds. London: Weidenfeld and Nicolson.

Rounsevell D.E., R.J. Taylor and G.J. Hocking 1991. Distribution Records of Native Terrestrial Mammals in Tasmania. Wildlife Research 18:699-717.

Ruddiman W.F. 2003. The anthropogenic greenhouse era began thousands of years ago. Climate Change 61(3):261-293.

Samways M. 1999. Translocating fauna to foreign lands: here comes the Homogenocene. Journal of Insect Conservation 3:65-66.

Schodde R. and J.H. Calaby 1972. The Biogeography of the Australo-Papuan Bird and Mammal Faunas in Relation to the Torres Strait. In D. Walker (ed) Bridge and Barrier: The Natural and Cultural History of Torres Strait, pp257-300.. Canberra: Department of Biogeography and Geomorphology, Research School of Pacific and Asian Studies, Australian National University.

Short J., S.D. Bradshaw J. Giles, R.I.T. Prince and G.R. Wilson 1992. Reintroduction of macropods (Marsupialia: Macropodoidea) in Australia - A review. Biological Conservation 62:189-204.

Simpson, G.G. 1961. Historical zoogeography of Australian Mammals. Evolution 15:431-46. Simpson, G.G. 1965. The Geography of Evolution: Collected Essays. Philadelphia: Chilton.

Smith M.J. 1973. Petaurus breviceps. Mammalian Species 30:1-5.

Souter G. 1963. New Guinea: The Last Unknown. Sydney: Angus and Robertson.

Spriggs M. 1997. The Island Melanesians. Oxford: Blackwell.

Strahan R. (ed.) 1995. The Mammals of Australia. Sydney: Australian Museum/Reed.

Summerhayes G.R. 2007. Island Melanesian Pasts: A View from Archaeology. In J.S. Friedlaender (ed) Genes, Language and Culture History in the Southwest Pacific, pp10-35. Oxford: Oxford University Press.

Swadling P. 1996. Plumes from Paradise: Trade cycles in outer Southeast Asia and their impact on New Guinea and nearby islands until 1920. Coorparoo: Papua New Guinea National Museum/Robert Brown and Associates.

Thomson G.M. 1922. The Naturalisation of Animals and Plants in New Zealand. Cambridge: Cambridge University Press.

Thorne, A., R. Grun, G. Mortimer, N.A. Spooner, J.J. Simpson, M. McCulloch, L. Taylor and D. Curnoe 1999. Australia's oldest human remains: age of the Lake Mungo 3 skeleton. Journal of Human Evolution 36:591-612.

Tinker S.W. 1941. Animals of Hawaii: A Natural History of the Amphibians, Reptiles, and Mammals Living in the Hawaiian Islands. Honolulu: Tongg Publishing Co.

Tinker S.W. 1980. A List of the Amphibians, Reptiles, and Mammals of the Hawaiian Islands (Exclusive of the Whales). Honolulu: Spencer Wilkie Tinker.

Tomich P.Q. 1969. Mammals in Hawaii: A Synopsis and Notational Bibliography. Bernice P. Bishop Museum Special Publication 57. Honolulu: Bishop Museum Press.

Tomich P.Q. 1986. Mammals in Hawaii: A Synopsis and Notational Bibliography, Second Edition. Bernice P. Bishop Museum Special Publication 76. Honolulu: Bishop Museum Press.

Tyndale-Biscoe H. 1973. Life of Marsupials. Melbourne: Edward Arnold.

Tyndale-Biscoe H. 2005. Life of Marsupials. Melbourne: CSIRO Publishing.

Van Deusen H.M. 1972a. Mammals. In P. Ryan (ed) Encyclopaedia of Papua and New Guinea, 3 volumes, pp688-694. Melbourne: Melbourne University Press / University of Papua and New Guinea.

Van Deusen H.M. 1972b. Marsupials. In P. Ryan (ed) Encyclopaedia of Papua and New Guinea, 3 volumes, pp711-714.. Melbourne: Melbourne University Press / University of Papua and New Guinea.

Van Dyck S. and R. Strahan 2008. The Mammals of Australia. Third Edition. Sydney: Reed New Holland. 
Waite E.R. and F.W. Jones 1927. The Fauna of Kangaroo Island, South Australia No.2 - The Mammals. Transactions and Proceedings of the Royal Society of South Australia 51:322-325.

Wallace A.R.1860. On the Zoological Geography of the Malay Archipelago. Zoological Journal of the Proceedings of the Linnean Society 4:172-184.

Wallace A.R. 1869. The Malay Archipelago: The Land of the Orang-utan, and the Bird of Paradise. New York: Harper and Brothers.

Wallace A.R. 1876. The Geographical Distribution of Animals: With a study of the relations of living and extinct faunas as elucidating the past changes of the Earth's surface. 2 Volumes. London: Macmillan and Co..

Wapstra J.E. 1976. Forester Kangaroo in Tasmania: Status and Management 1976. Wildlife Division Technical Report 76/1. Hobart: Tasmanian National Parks and Wildlife Service.

Warburton B. 2005a. Dama wallaby. In C.M. King (ed) The Handbook of New Zealand Mammals. Second Edition, pp32-39. Melbourne: Oxford University Press.

Warburton B. 2005b. Bennett's wallaby. In C.M. King (ed) The Handbook of New Zealand Mammals. Second Edition, pp39-45. Melbourne: Oxford University Press.

Warburton B. 2005c. Parma wallaby. In C.M. King (ed) The Handbook of New Zealand Mammals. Second Edition, pp45-49. Melbourne, Oxford University Press.

Warburton B. 2005d. Black-striped wallaby. In C.M. King (ed) The Handbook of New Zealand Mammals. Second Edition, pp49. Melbourne: Oxford University Press.

Warburton B. 2005e. Brushtailed rock wallaby. In C.M. King (ed) The Handbook of New Zealand Mammals. Second Edition, pp50-53. Melbourne: Oxford University Press.

Warburton B. 2005f. Swamp wallaby. In C.M. King (ed) The Handbook of New Zealand Mammals. Second Edition, pp53-55. Melbourne: Oxford University Press.

Weidenhofer M. 1977. Maria Island, a Tasmanian Eden. Hobart: Darlington Press.

Whitten T., G.S. Henderson and M. Mustafa 1987. The Ecology of Sulawesi. Singapore, Periplus Editions.

Wickler S. 2001. The Prehistory of Buka: A Stepping Stone Island in the Northern Solomons. Terra Australis 16. Canberra: Department of Archaeology and Natural History, and Centre for Archaeological Research, Australian National University.

Wodzicki K.A. 1950. Introduced Mammals of New Zealand: An Ecological and Economic Survey. Bulletin No. 98. Wellington: New Zealand Department of Scientific and Industrial Research.

Wodzicki K.A. and J.E.C. Flux 1971. The Parma Wallaby and its Future. Oryx 11(1):40-47.

Yalden D. 1982. When did the mammal fauna of the British Isles arrive? Mammal Review 12(1):1-57.

Yalden D. 1991. History of the Fauna. In G.B. Corbet and S. Harris (eds) The Handbook of British Mammals, Third Edition, pp7-18.Oxford: Blackwell Scientific Publications.

Yalden D. 1999. The History of British Mammals. London: T. and A.D. Poyser.

Yalden D. and G.R. Hosey 1971. Feral wallabies in the Peak District. Journal of Zoology, London 165:513-520.

Young D. 2004. Our Islands, Our Selves: A History of Conservation in New Zealand. Dunedin: University of Otago Press.

Ziegler A.C. 1977. Evolution of New Guinea's marsupial fauna in response to a forested environment. In B. Stonehouse and D. Gilmore (eds) The Biology of Marsupials, pp117138. Baltimore: University Park Press.

Ziegler A.C. 1982. An ecological check-list of New Guinea Recent mammals. In J.L. Gressitt (ed) Biogeography and Ecology of New Guinea, pp863-894. The Hague: W. Junk.

Ziegler A.C. 2002. Hawaiian Natural History, Ecology, and Evolution. Honolulu: University of Hawaii Press. 